\title{
Bankruptcy Costs and the Design of Preventive
}

\author{
Restructuring Procedures
}

\author{
Anne Epaulard Chloé Zapha*
}

November 2020

\begin{abstract}
A European directive requires Member States to give firms access to preventive restructuring procedures. This paper assesses the interest of a procedure distinct from that for insolvent firms. It is based on the French experience, where a preventive procedure has coexisted with the more common restructuring procedure since 2006. The spatial and temporal heterogeneity of the Commercial Courts' decisions allows the identification of the causal impact of the conversion from the preventive procedure to the common one on the firm's survival chances. Using an (almost) exhaustive sample of preventive bankruptcy filings over 2010-2016, we show that conversion reduces the probability of firm survival by 50 p.p., which corresponds to indirect bankruptcy costs of around $20 \%$ of the firm assets. Our interpretation is that the low restructuring rate under the common bankruptcy procedure may alarm some of the firm's stakeholders, especially its customers. This in turn aggravates the firm's difficulties and reduces its chances of restructuring under the common procedure. We provide some empirical evidence to support this interpretation. A distinct preventive procedure helps prevent this spiral.
\end{abstract}

\footnotetext{
*Anne Epaulard is with PSL University of Paris-Dauphine and France Stratégie: anne.epaulard@dauphine.psl.eu, Chloé Zapha is with PSL University of Paris-Dauphine and France Stratégie: chloe.zapha@dauphine.eu. A previous version of this paper circulated under the title "Using Heterogeneity in Commercial-Court decisions ot Measure the Indirect Costs of Bankruptcy Filing in France". We thank Governance Analytics PSL for their help in exploiting the BODACC database and the CNAJMJ for sharing their database with us. This work is supported by a public grant overseen by the French National Research Agency (ANR) as part of the "Investissements d'avenir" program (reference: ANR-10-EQPX-17 Centre d'accès sécurisé aux données CASD). This paper has benefited from discussions with professionals involved in either the judicial process for bankruptcy procedures or its regulation in France. These include Christophe Basse, Guy Lalanne, Jerôme Mandrion, Julien Rosier and Christophe Thevenot. We are grateful to Christophe Cahn, Eve Caroli, Jens Dammann, Clement Dherbecourt, Miguel García-Posada Gómez, Fernando Gómez, Claire Lelarge, Alessandro Melcarme, Gianluca Orefice, Aude Pommeret, Jean-Luc Schneider and Marianne Verdier for insightful comments and discussions. We also thank seminar participants at the 18th Journées Louis-André Gérard-Varet of the Aix-Marseille School of Economics, the Nanterre International Meeting in Law and Economics, Paris-Dauphine University, University of Paris II Panthéon-Assas, the 2019 German Law \& Economics Association conference, the 2019 Spanish Association of Law and Economics conference and the 2019 French Economic Association meeting. The opinions and conclusions expressed herein are solely those of the authors and do not represent the policy or opinions of France Stratégie or any agency of the French government.
} 
Pioneer in online sales, Pixmania files for Sauvegarde

Le Monde - October 27, 2015

Pixmania soon in Receivership

Le Monde - January 6, 2016

Pixmania in Receivership: don't order anymore!

Le Monde - January 26, 2016

\section{Introduction}

In 2019, an EU directive invited Member States to introduce into their commercial laws a court-supervised preventive procedure for businesses $1^{1}$ The rationale for a preventive procedure is that the sooner a firm's difficulties are addressed, the greater its chances of survival. This EU initiative reflects a recent general interest in preventive procedures, as exemplified by the recent OECD study in which the existence of a preventive procedure is considered as a good idea 2

There are two ways of introducing a preventive procedure into commercial law. One can either just extend existing bankruptcy procedures to allow firms that are on the verge of insolvency to file for it - as is the case in US Chapter 11 - or create a specific procedure exclusively for these firms. In this paper, on the basis of an empirical analysis on the French experience of the preventive procedure introduced in 2006, we argue that if the existing bankruptcy procedure entails low survival rates for firms, it might be more efficient to create a specific procedure. The reason is that the specific procedure would serve as a signal for stakeholders that firms allowed to file for it are in a relatively better financial situation than firms entering the regular bankruptcy procedure. That would help reduce indirect bankruptcy costs and thus preserve the survival chance of these firms.

It is well known that firms usually prefer out-of-court restructuring as it better preserves their reputation vis-a-vis not only their creditors and suppliers, but also their clients and employees. Yet, out-of-court restructuring is not always possible, as it generally requires consensus

\footnotetext{
${ }^{1}$ cf. https://eur-lex.europa.eu/legal-content/EN/TXT/PDF/?uri=CELEX:32019L1023

${ }^{2}$ McGowan M.A. et Andrews D. (2018), "Design of insolvency regime across countries," OECD Economic Department Working Paper, 1504.
} 
amongst creditors involved in the restructuring process, and restructuring agreements cannot be extended to other creditors. Also, out-of-court restructuring can suffer from coordination problems amongst creditors (see Morris and Shin (2004)). For firms that are already insolvent, the usual path is to file for bankruptcy. Once the firm files for bankruptcy, its financial difficulties are exposed and its reputation suffers. The firm has then to convince its clients, trade creditors, employees and suppliers to carry on doing business with it. Costs associated with reputational losses are part of the indirect costs of bankruptcy ${ }^{3} \mathrm{~A}$ bankruptcy procedure specific to fragile but still solvent firms might reduce reputational losses and better preserve survival chances. This is all more the case given that the usual bankruptcy procedure has low survival rates.

To test the hypothesis that a specific procedure better preserves survival chances, we take advantage of the coexistence in France of two court-supervised debt-restructuring bankruptcy procedures: the Redresssement Judiciaire (RJ) for insolvent firms, and the "Sauvegarde" procedure available to firms that are not yet insolvent. These two bankruptcy procedures yield radically different results in terms of the success of debt restructuring. We use the fact that Commercial Courts convert some cases from the "good" bankruptcy procedure (Sauvegarde) to the "not as good" one (RJ) to identify the reduced restructuring chances and survival rate associated with conversion to RJ. The identification strategy also relies on the heterogeneity in the Court $\times$ Year conversion rates. We apply our identification strategy to an (almost) exhaustive sample of Sauvegarde bankruptcy filings in France over the 2010 - 2016 period, their outcomes up to December 2018, and their survival up to May 2020.

Two bankruptcy procedures The main bankruptcy procedure available to French firms seeking a debt-restructuring deal with their creditors is known as the Redressement Judiciaire (RJ). In its current form, it dates from 1985. In many dimensions the RJ is similar to the US Chapter 11 procedure, differing only in that only firms that are already in a precarious financial situation can (and must) file for it, or be liquidated. Depending on the economic situation,

\footnotetext{
${ }^{3}$ In addition to lost sales and profit, these indirect costs arise due to inter- or intra-group conflicts of interest, asymmetric information, hold-out problems, higher operating costs, and the ineffective use of management time Altman (1984), Opler and Titman (1994), Bris et al. (2006), Almeida and Philippon (2007)). These indirect costs are difficult to measure, but are commonly viewed in the literature as being substantial, at up to $20 \%$ of firm asset value (e.g. Andrade and Kaplan (1998), Bris et al. (2006), Hotchkiss et al. (2008), Davydenko et al. $(2012)$.
} 
between 30,000 and 50,000 firms enter an RJ each year. After an observation period that can last for up to 18 months, the firm either reaches an agreement with its creditors to restructure its debt or is liquidated 4 This bankruptcy procedure has a low firm-survival rate. In the dataset we construct, of all initial RJ filings in France over the 2008 - 2016 period (and their outcomes up to December 2018 and survival up to May 2020), only around 30\% of firms entering RJ manage to restructure their debt, with the others being liquidated. Creditors recovery rates are much lower when the firm is liquidated than in RJ 5

In 2006, a new court-supervised bankruptcy procedure, called Sauvegarde (Safeguarding) was introduced into French commercial law. This new procedure aims to give firms time to restructure their debts and business before they reach the poor financial situation that triggers RJ filing. Although most of the law's provisions in this bankruptcy procedure are similar to those for RJ, Sauvegarde has better results: in our dataset, around $65 \%$ of firms filing for Sauvegarde manage to restructure their debts. This higher restructuring rate is a consequence of the better financial situation of Sauvegarde filers; it might also reflect pro-active managers who are willing to act early to solve their firms' financial difficulties. It could also reflect that some or all stakeholders evaluate the Sauvegarde procedure in a more positive way than RJ, as discussed below.

The role of bankruptcy announcement on stakeholders' behavior As early as 1984, Altman highlighted that a bankruptcy filing can trigger changes in the behavior of clients, who become reluctant to deal with a firm in bankruptcy. This results in lost sales and profits. There is indeed some empirical evidence that the behavior of customers changes after a bankruptcy announcement. In the automotive industry, Hortaçsu et al. (2013) shows that after a car manufacturer files for bankruptcy, the price of its cars falls in the second-hand market. Empirical literature has also shown that firms in bankruptcy respond to the threat of a drop in demand for their product by reducing their price (Borenstein and Rose (1995), Ciliberto and Schenone (2012), Phillips and Sertsios (2013)). This supports the idea that what is at stake af-

\footnotetext{
${ }^{4}$ When liquidated, the firm's assets are either sold to a single buyer with the aim of keeping the firm as a going concern (potential buyers compete by sending bids to the Court, which then chooses among them), or put on the market as the firm is wound down.

${ }^{5}$ Data on the recovery rates for creditors are difficult to find. Blazy et al. (2018) calculate that, in a small sample of 264 cases opened in the Paris Commercial Court, the recovery rates in liquidation are as low as $34.9 \%$ for secured creditors and $5.0 \%$ for unsecured creditors, as compared to $75.5 \%$ and $73.1 \%$ respectively in continuation.
} 
ter a bankruptcy filing is not only the goodwill of creditors but also the demand for the product of the firm. Indeed, the communication of firms filling for bankruptcy often aims at reassuring the firm's customer ${ }^{6}$ more than its creditors (who already have all the information, and whose coordination is ensured by the court).

In the same vein, the announcement of the conversion of a case from one bankruptcy procedure to the other can trigger changes in the behavior of some or all of the firm's stakeholders. This can be illustrated by the way newspapers report on bankruptcy procedures. An extreme example is that of Pixmania, a French e-commerce company founded in 2000, that filed for Sauvegarde in 2015. On October 27, 2015, the French newspaper Le Monde ran a short article with a somewhat flattering title, "Pioneer in online sales, Pixmania is placed in safeguard procedure." This short article highlights that the aims of the court-appointed Administrator is to "assist management in the implementation of a new operating model designed to make the firm profitable on a sustainable basis." On January 6, 2016, the same newspaper ran a short article about the likely conversion of the case to RJ. Then on January 26, after some consumers reported not receiving their orders, it ran a new article with the alarming title, "Pixmania in RJ: don't order anymore!". Delays in shipments happen all the time, but in the case of Pixmania, the fact that the company was in RJ triggered an overreaction by the newspaper... and maybe the clients of the firm. In any case, Pixmania didn't restructure its debt and was liquidated.

To better understand the role of reputational losses on survival chances, one can consider that there are two types of stakeholders in firms in a Safeguard procedure : sophisticated stakeholders (the main creditors and main suppliers, who are directly involved in the restructuring process) and less-sophisticated ones (clients, potential clients, potential suppliers, and even employees in some cases). The sophisticated stakeholders are aware of the overall financial situation of the firm in Sauvegarde, and conversion to RJ is unlikely to deliver much new information to them. This is less true for less-sophisticated stakeholders, who do not likely follow the day-to-day financial situation of the firm. While filing for Sauvegarde appears quite benign to them (which is supported by the high rate of restructuring in Sauvegarde), conversion to RJ (a procedure with low restructuring rates) may sound alarming. These less-sophisticated stakeholders may decide to stop contracting with the firm altogether, no matter its actual fi-

\footnotetext{
${ }^{6}$ For example, Altman (1984) points to the efforts made by Chrystler's management to maintain public confidence in the firm's ability to continue after it filed for bankruptcy.
} 
nancial situation. This may turn out to be a self-fulfilling prophecy that further worsens the firm's situation and thus reduces its chances of restructuring.

Identification strategy To measure the impact of RJ on restructuring, we rely on the fact that a significant share of Sauvegarde cases are subsequently converted into RJs by Courts, as was the case for Pixmania. This allows us to use data only on bankruptcy cases that started as Sauvegarde, thus avoiding the selection bias associated with Sauvegarde filing relative to RJ filing. The Court can convert a Sauvegarde case to an RJ if the assessment of the firm's financial situation reveals that it is already insolvent or on the verge of insolvency. However, the exact trigger for conversion may be interpreted differently across Commercial Courts and over time. In our sample, $14.2 \%$ of Sauvegarde cases that were opened over the period 2010 - 2016 were subsequently converted into RJ. We find considerable heterogeneity in this yearly conversion rate over the 134 French Commercial Courts, ranging from $0 \%$ to $100 \%$; this gap remains substantial even when we control for local firm characteristics and economic conditions. Part of this heterogenity may come from the turnover 7 f lay judges 8 . We use this heterogeneity in Court $\times$ Year conversion rates to construct an instrument to identify the impact of conversion on the probability of successful debt-restructuring. It is important to note that the firm's assignment to a Commercial Court is based on the location of the firm's headquarters. This prevents firms from forum-shopping. This also means that given administrative boundaries, some firms are not assigned to the closest Commercial Court. We draw on this fact to confirm that it is the firm's assigned Court rather than the one closest to it that matters, in order to rule out any concern that results are driven by local economic conditions.

Results Overall our empirical results suggest that conversion to RJ reduces the chance of debt restructuring by 50 percentage points. It also reduces by 40 percentage points the survival rate of firms at the five-year horizon. The exclusion-restriction is validated by checking that the probability of reaching a debt-restructuring agreement for firms that enter RJ directly is not correlated with the instrument. Additional results suggest that firms in sectors that are more

\footnotetext{
${ }^{7}$ Commercial Court judges in France are non-professional, elected from among local business leaders and executives for limited terms. There is a partial yearly turnover in these lay judges.

${ }^{8}$ See also Iverson et al. (2019) for the role of judges' experience in the outcome of bankruptcy procedure.
} 
likely to suffer from reputational losses once converted, are indeed more impacted by conversion. In addition, we carry out various robustness checks, none of which affect the results. A backof-the-envelope calculation based on our results suggests indirect costs associated with RJ of about $20 \%$ of the total book asset value of the firm.

The remainder of the paper is organized as follows: Section 2 presents the two French bankruptcy procedures and our original dataset. Section 3 discusses the heterogeneity of Commercial Courts in France, and Section 4 then presents the identification strategy and the firststage results. Section 5 contains our main econometric results, a discussion of their implications, and the robustness checks. Lastly, Section 6 contains our conclusions.

\section{Bankruptcy Procedures in France and Their Outcomes}

\subsection{Bankruptcy procedures}

There are two different procedures for a firm seeking Court-supervised debt restructuring in France: Sauvegarde and RJ. The main difference between the two is the extent of the financial difficulties that the firm faces. An insolvent firm has access to RJ, while a firm that is not (yet) insolvent, but can prove that it is facing serious financial problems, has access to Sauvegarde. Table 1 summarizes the main features of the two procedures, both of which resemble the US Chapter 11 bankruptcy procedure $9^{9} \operatorname{In}$ addition to these two procedures there exists a standard liquidation procedure (akin to US Chapter 7).

\section{The RJ procedure}

French commercial law is such that a firm that cannot meet its payment obligations is considered insolvent if these are not covered by its liquid assets. Unless it starts an out-of-court restructuring, an insolvent firm has to file for an RJ within 45 days to start a debt-restructuring process with its creditors. In practice, some insolvent firms do not respect this 45-day limit, and here the firm's creditors, as well as the Court itself, can bring the case before the Court to trigger an RJ. Insolvent firms can also file directly for liquidation.

Once the firm files for RJ, it is protected from its creditors and the payments of interest

\footnotetext{
${ }^{9}$ For additional comparisons between American and French bankruptcy procedures, see Plantin et al. (2013).
} 
and principal are suspended. The firm also has access to a loan to pay up to three months of wage arrears to its employees ${ }^{10}$ There is a six-month observation period to assess the financial situation of the firm. During this period a Court-appointed Receiver is in charge of establishing the list of the firm's liabilities. The Court also nominates an Insolvency Administrator to monitor the firm's day-to-day operations, notably all of its financial transactions as well as some major restructuring decisions (firing employees, selling assets, etc.). The Administrator can also prevent the firm's manager from undertaking actions that would reduce the firm's asset value. The Administrator and the Receiver negotiate with creditors to establish a debt-restructuring plan. The observation period can be renewed twice, and so lasts for a maximum of 18 months. At any time during the observation period, the Court can accept (or reject) a debt-restructuring plan negotiated with creditors. The typical plan is a mixture of debt-rescheduling (up to a 10year horizon) and a haircut (if, given the option, some creditors prefer an immediate partial payment to settle the final balance, over rescheduling). If the situation deteriorates further during the observation period and/or there is no hope of reaching an agreement with creditors, the Court can decide to liquidate the firm. Liquidation can take two forms. In the most abrupt form, the firm's assets are sold on the market, with the proceeds going to the firm's stakeholders according to priority rules (with employees having the highest priority for unpaid wages). A smoother form of liquidation consists in the opening of a bidding process for all or part of the firm's assets and some or all of its employees, with the view to keeping at least part of the firm as a going concern. The Court receives bids from potential buyers and chooses amongst them. If there are no buyers, or if the Court rejects all of the offers, the firm ceases operations, its assets are sold, and stakeholders are reimbursed according to the same priority rule as above.

\section{The Sauvegarde procedure}

In 2006, in order to allow earlier debt-restructuting, a new bankruptcy procedure was introduced in French commercial law ${ }^{11}$, known as the Sauvegarde procedure. Firms can file for Sauvegarde if they are not (yet) insolvent, but face financial difficulties that they consider impossible to overcome without debt-restructuring. After a rapid background check of the firm's financial

\footnotetext{
${ }^{10}$ This scheme is funded by a mandatory contribution based on each private firm's wage bill. At the macro level, the contribution rate is adjusted so as to keep the fund balanced. Since July 2017, this rate has been $0.15 \%$.

${ }^{11}$ The Bankruptcy Protection Act of July 26, 2005 came into force on January 1, 2006.
} 
situation, the Court accepts (or rejects) the Sauvegarde filing. Sauvegarde filing can be rejected if the firm appears to already be insolvent (in which case an RJ procedure is opened) or, on the contrary, if the Court considers that the financial situation does not require debt-restructuring.

Once the Sauvegarde filing is accepted by the Court, the steps are quite similar to that of the RJ procedure: the proceedings are public 12 the six-month observation period is twicerenewable, and the Court appoints a Receiver. The Court can also appoint an Administrator, and is required to do so for the largest firms (in RJ, the Court appoints an Administrator regardless of firm size). The role of the Administrator is less important in Sauvegarde than in RJ: he or she only assists the manager and cannot make decisions without the consent of the manager, whereas he or she can in RJ. An important difference between the Sauvegarde and RJ procedures is that in Sauvegarde the firm does not have access to a loan from the insurance scheme to pay for wage arrears. Table 1 summarizes the main features of the two procedures.

\section{Conversion from Sauvegarde to RJ}

As stated by the law, the Court can convert a Sauvegarde case into an RJ at any moment in time during the observation period if the assessment of the financial situation reveals that the firm was already insolvent at the time it filed for Sauvegarde, has become insolvent, or is currently on the verge of insolvency. The Court will consider conversion at the request of the Administrator, the Receiver, the Public Prosecutor's Office, or (since September 2014) the firm itself. Up to July 2014, the judge him- or herself could carry out this conversion.

Discussions with various bankruptcy-procedure stakeholders have led us to hypothesize that, in practice, there are (at least) three different situations that can potentially trigger a conversion decision. In the first, a careful examination of the firm's financial accounts, often with the help of Chartered Accountants appointed by the Court, raises doubts that the firm was still solvent at the time it filed for Sauvegarde. In the second situation, the firm runs out of cash during the observation period and defaults on the financial obligations it contracted after filing for Sauvegarde. In addition to these two situations, which fit the wording of the law fairly well, a third situation was once mentioned during our discussions with stakeholders: the Court may consider that the measures being taken by the debtor are endangering the firm. The Court

\footnotetext{
${ }^{12}$ All openings of bankruptcy procedures (Sauvegarde, RJ and Liquidation), as well as all of the main Court decisions during the procedures, are available in a daily publication that has appeared online since 2008.
} 
then converts the case to an RJ so as to appoint an Insolvency Administrator of its choice to run the company. It is worth noting that the conversion of Sauvegarde to RJ does not grant access to a loan to pay for wage arrears (whereas direct RJ entry does).

\subsection{Data and bankruptcy-procedure outcomes}

The data used here come from bankruptcy filings contained in the Bulletin Officiel d'Annonces Civiles et Commerciales (BODACC), provided by the registry offices of the Commercial Courts. This information is public and is available in electronic form since January 2008, in the form of one electronic file per business day ${ }^{13} \mathrm{We}$ constructed a dataset of all bankruptcy filings in France over the 2010 - 2016 period and followed their outcomes up to December 2018 and their survival up to May 2020. Our dataset contains 324,748 filings: ${ }^{14} \beta, 070$ Sauvegarde filings, 96,105 RJ filings, and 220,573 direct liquidations. We are able to follow up on 7,927 Sauvegarde cases (98\%) and 95,017 RJ cases (99\%), which constitute our initial sample. By definition, there is no follow-up for liquidations. From BODACC, we are able to gather information on the firm's address, the Commercial Court in charge of the case, the dates of filing, and the subsequent main judgments by the Court (renewal of the observation period, agreement on debt-restructuring with creditors, liquidation, etc.). We can notably identify the Sauvegarde cases that are converted to RJ.

We restrict the sample of Sauvegarde-filing firms so as to exclude firms which were liquidated within six months after their filing. This allows us to eliminate obvious errors in the orientation of firms between procedures (restructuring vs. liquidation) and to concentrate our work on firms with reasonable chances of restructuring 15

We complement these data with firm economic and financial information from the balance sheets and income statements made available by INSEE, the French Statistical Office, over the 2009 - 2015 period. This provides us with the last available information on each firm before it filed for bankruptcy, including data on the number of employees, total assets and their structure

\footnotetext{
${ }^{13}$ See https://www .data.gouv.fr/fr/datasets/bodacc/.

${ }^{14}$ These numbers are below those reported by Altares, a privately-owned company that produces statistics on bankruptcy filings in France. Our sample is restricted to Commercial Courts. As such, it excludes bankruptcy filings from farmers, the self-employed, and professional practices. It also excludes Courts in three French metropolitan Départments as well as overseas territories (see footnote 19p.

${ }^{15}$ This operation removes 656 Sauvegarde-filing firms from our sample. We thank Claire Lelarge for this suggestion.
} 
(financial, tangible, and intangible), total debt and its structure (banks, suppliers, and other), interest payments, total sales, operational income, industry, age, legal status, and so on. After matching, our final sample contains 5,678 Sauvegarde cases, 805 (14.2\%) of which were converted to RJ, and 66,849 RJ filings, of which 39,565 were voluntary filings (with the others triggered by either creditors or the Court itsel ${ }^{16}$.

\section{Summary statistics}

Table 2 presents a breakdown of the number of Sauvegarde filings in our final sample per year over 2010 - 2016. The number of filings increased steadily up to slightly over 900 cases per year until 2013, stabilized in 2014, and then fell below 800 in 2016. Over the period 2010 - 2016, Sauvegarde filings represent between $10.7 \%$ and $13.3 \%$ of court-supervised reorganisations. The vast majority of court-supervised reorganisations are RJ procedures.

The outcomes of the Sauvergarde procedure are summarized in Table 3 . In the full sample over the 2010 - 2016 period, $69.7 \%$ of Sauvegarde-filing firms manage to restructure their debt with their creditors (column (1)), against $27.3 \%$ only for RJ-filing firms (column (5)). From this point of view, the Sauvegarde procedure has a higher percentage of restructuring deals than US Chapter 11.17

In our final sample over 2010 - 2016, 71.9\% of the firms filing for Sauvegarde restructured their debt, a figure higher than that of RJ. $80.9 \%$ of the firms that reached a deal with their creditors in Sauvegarde are still operating two years after the deal, while this is the case for $71.1 \%$ of RJ firms. When we look at the survival rate after filing for bankruptcy, irrespective of whether the firms reached a debt-restructuring agreement, $60.6 \%$ of Sauvegarde-filing firms are still alive three years into the procedure, against $23.9 \%$ for RJ-filing firms. These numbers do not, however, necessarily prove the superiority of Sauvegarde over RJ, as firms entering these two bankruptcy procedures do not start with the same level of financial distress. By design, firms filing for Sauvegarde have less-severe financial problems than those filing for RJ. They may also have unobservable characteristics distinguishing them from those filing for RJ, that affect

\footnotetext{
${ }^{16}$ The information regarding the nature of the RJ filing is provided by the Conseil National des Mandataires Judiciaires et Administrateurs Judiciaires, an association of Court-appointed Receivers and Insolvency Administrators.

${ }^{17}$ Bernstein et al. (2019b) note that in their large sample, around $40 \%$ of Chapter 11 cases were converted to liquidation.
} 
the outcome of the bankruptcy procedure: being more proactive, or having a better-informed management. Our identification of the effect of RJ will thus examine the fate of firms that initially filed for Sauvegarde and were subsequently converted into RJ by the Court.

Amongst the Sauvegarde filings, $14.2 \%$ were subsequently converted into RJ. For firms whose Sauvegarde filings were converted into RJ, the probability of reaching a debt-restructuring agreement with their creditors is $23.2 \%$, a rate lower than that for voluntary RJ filings $(41.2 \%)$, and much lower than that of firms whose Sauvegarde filings were not converted into RJ (79.9\%). For firms that manage to restructure their debt, the two-year survival rate for firms converted to $\mathrm{RJ}$ is $84.4 \%$, slightly higher than for cases that remained in the Sauvegarde procedure up to the end $(80.8 \%)$, but the difference is not statistically different from zero. The analogous four-year survival rates are $60.6 \%$ and $68.2 \%$ respectively. The unconditional survival rates, however, three and five years after filing for Sauvegarde, are respectively $67.4 \%$ and $53.2 \%$ for firms whose Sauvegarde filings were not converted to RJ, and $19.9 \%$ and $14.4 \%$ exclusively for firms whose Sauvegarde filing were converted to RJ. These differences are statistically significant are the $1 \%$ level.

Regarding the financial and economic situation of our sample firms, those whose Sauvegarde filings are converted into RJ are on average older than the firms whose Sauvegarde filings are not (13.6 versus 11.7 years old), have more supplier debt (29.4\% of their total debt vs. $25.7 \%$ ), lower fixed assets (49.3\% of their total assets vs. $55.4 \%$ ) and are more likely to be labelled as "zombies" 18 (66.1\% vs. 56.5\%). A simple test of the equality of means reveals that these differences are statistically different from zero (see column (4) of Table 3 ).

\footnotetext{
${ }^{18}$ We label a firm as a "zombie" if its financial obligations were greater than its operational income the year before the filing. Our definition is slightly different from that used by the OECD (see Adalet McGowan et al. (2017)), for which "zombie" firms are over ten years old with financial obligations greater than operational income for over three consecutive years.
} 


\section{Heterogeneity in Commercial-Court Decisions}

\subsection{Commercial Courts and lay judges}

There are currently 134 Commercial Courts and 28 Courts of Appeal spread out over France ${ }^{19}$ There is at least one Commercial Court in each of the 95 Départements, with some Départements having two or even three. These Courts deal with bankruptcy proceedings for companies and commercial disputes, with the former representing $20 \%$ of the cases they hear. In bankruptcy hearings, the firm is assigned to a Court according to the firm's headquarters' location, and there is no possibility of forum shopping by either the firm or its creditors. Note that, given administrative boundaries, firms are not necessarily assigned to the closest Commercial Court, a fact that we will exploit later for identification purposes.

There are around 3,000 commercial lay judges. These are chosen from among business leaders and executives and elected by them. Judges are unpaid volunteers; they sit only one or two half-days per week, and carry on with their normal business activities the rest of the time. For obvious reasons, they cannot work on cases related to their own businesses. Each judge is initially elected for a two-year term, and can then be re-elected three times for a four-year term (for a maximum service of 14 years). There is one election per year at the Court level, and the terms start in early January. There is thus regular turnover amongst judges. Judges elect from amongst their number the President of the Court as well as two vice-presidents for a four-year term that is not renewable. Judges receive legal training both after being chosen and during their term of office. A typical hearing involves more than one judge, as Courts are organized by chambers. Each case is allocated to a specific judg ${ }^{20}$, but decisions are taken by the judges of the chamber by consensus.

\section{$3.2 \quad$ Heterogeneity}

Our identification strategy, which we present in Section 4, is based on the observation that while French bankruptcy law is national, its interpretation can differ from one Court to another, and

\footnotetext{
${ }^{19}$ While French commercial law does not differ from one Court to another, we exclude some parts of France from our research: the Courts in three Départements (Moselle, Haut-Rhin and Bas-Rhin) as, for historical reasons, they operate somewhat differently from Courts in the rest of the country, and overseas Départements and Territories for the same reason. Esquerré (2019) shows that Courts in Alsace-Moselle deal differently with bankrupt firms.

${ }^{20}$ Note that the name of the judge to whom the case is assigned is not available in our database.
} 
over time. This is especially true for the conversion decision from Sauvegarde to RJ, which is based on the notion of insolvency or "closeness to insolvency." Here insolvency means that short-term debt is greater than the firm's liquid assets. There is some room for interpretation of the firm's financial situation, as not only the valuation of the firm's liquid assets but also the meaning of "close to insolvency" can differ from one Court to another (depending, for example, on their Chartered Accountants). In addition, the Courts' interpretation of the law may vary by place and over time, notably because of the regular arrival of inexperienced judges. Iverson et al. (2019) show that, in the United States, the outcome of bankruptcy procedures varies with the judges' experience. Our instrument relies on these heterogeneities, which we discuss below.

\section{Court heterogeneity}

There is great heterogeneity amongst Commercial Courts, both in terms of their size and the outcomes of their procedures. Regarding heterogeneity in Court size, Table 4 shows that, over the 2010 - 2016 period, on average around 2,414 new bankruptcy cases (direct liquidations, RJs and Sauvegardes) were opened, with the smallest Court registering only 273 cases and the largest one almost 20,000. The smallest Court has only nine judges and the largest 180. The share of Sauvegarde filings amongst restructuring filings (that is, excluding direct Liquidations) is on average $8.1 \%$ but with considerable variation, with one Court registering $32.6 \%$ Sauvegardes. Regarding outcomes, heterogeneity between Courts is larger for Sauvegardes than for RJs. The average Court reaches a restructuring deal in $57.9 \%$ of its Sauvegarde cases, with a range from $20 \%$ to $93 \%$. This range is much narrower for RJs, at $15 \%$ to $48 \%$ with a mean of $31 \%$. The share of Sauvegarde cases converted to RJ is also heterogeneous across Courts, with a range from 0 to $50 \%$. This is depicted in Figure 2, which maps the average conversion rate of Courts over the 2010 - 2018 period. High conversion rates (over 21.7\%) are found everywhere, North and South, East and West, and do not necessarily correspond either to large cities or rural areas. For example, Toulouse and Lille have amongst the highest conversion rates (a 29\% and $28 \%$ share of cases converted, respectively) while other large cities like Bordeaux and Paris are in the second quartile (with figures of $19 \%$ and $13 \%$ respectively). Looking at rural areas $21 \mathrm{t}$ is striking that two adjacent jurisdictions that deal with the same type of firms, Cahors and Aurillac, have very different conversion rates ( $5 \%$ and $36 \%$ respectively). The same applies to

\footnotetext{
${ }^{21}$ Farmers' bankruptcies are not included in our sample as they are dealt with in specific Courts.
} 
the Courts in Montauban and Albi in the South-West of France (3\% and 29\% respectively), which are mid-sized cities in the greater periphery of Toulouse.

\section{Time variation within Courts}

There is not much variation over time in Court size, measured as either the number of Judges or the number of bankruptcy-case openings. There is much more time variation within Courts in other indicators, notably in the decisions to convert Sauvegarde cases into RJ. The variation in conversion rates within courts actually explains $80 \%$ of the total variance in the Court $\times$ Year conversion rates. This heterogeneity within courts can be the result of the overall or local economic situation, the regular turnover in lay judges, or other potential unobservable factors.

\section{Identification Strategy}

Our identification strategy builds on a number of empirical studies using heterogeneity in judicial decisions as an instrument to measure the impact of decisions. For example Bernstein et al. (2019a) and Bernstein et al. (2019b) use the judicial conversion rate of Chapter 11 cases to Chapter 7 to explain the reallocation of assets and bankruptcy spillovers. In a different field, Maestas et al. (2013) use examiner heterogeneity in granting disability benefits to measure the impact of receiving these benefits on labor supply. Their identification strategies are based on the random allocation of judges or examiners to cases. Unlike these contributions, we do not have data on judges but only on Commercial Courts, and the allocation of bankruptcy cases to Courts is not random, as it depends on the location of the firm's headquarters. To ensure that our strategy is valid, we carry out a number of empirical tests to show that the experiment approaches random assignment once we control for firm-specific characteristics.

\subsection{Empirical design}

To measure the impact of RJ compared to that of Sauvegarde, we focus on firms that initially filed for Sauvegarde and exploit the fact that a significant fraction of Sauvegarde cases $(14.2 \%)$ are subsequently converted into RJ by Courts. This allows us to eliminate the unobservable characteristics of firms that file for Sauvegarde as compared to RJ. 
Following Bernstein et al. (2019b), our model specification is:

$$
Y_{i, j, t^{\prime}}=\alpha+\beta \cdot \text { Conversion }_{i, j, t^{\prime}}+\gamma_{1} X_{i, t}+\mu_{s, t^{\prime}}+\mu_{j}+\epsilon_{i, j, t^{\prime}}
$$

Here $Y_{i, j, t^{\prime}}$ is the dependent variable, the probability that firm $i$ assigned to Court $j$ restructures its debt, with $t^{\prime}$ the year at the end of the observation period, which we will refer to as the judgment year. Conversion ${ }_{i, j, t^{\prime}}$ is a dummy for the Sauvegarde case $i$ having been converted to RJ at $t^{\prime}$ in Court $j$. We wish to estimate $\beta$, the effect of RJ conversion on $Y_{i, j, t^{\prime}}$. $X_{i, t}$ is a set of firm-level characteristics measured the year before the filing. We include dummies $\mu_{s, t^{\prime}}$ for industry $\times$ year-of-judgment fixed effects and dummies $\mu_{j}$ for each Court. Under the null hypothesis that RJ conversion has no effect on $Y_{i, j, t^{\prime}}, \beta$ should not be statistically different from zero, while a negative value of $\beta$ means that $\mathrm{RJ}$ conversion reduces the chances of debt restructuring. We use a standard IV-2SLS model, as recommended in the literature Angrist and Pischke (2008)). The standard errors are clustered at the Court $\times$ Year-of-judgment level.

We will later also consider the dependent variable $Y_{i, j, t^{\prime}}$ as firm survival at the horizons of two and five years after the agreement with the firm's creditors has been reached.

The vector $X_{i, t}$ contains firm financial variables such as the ratio of fixed to total assets, the structure of the asset (financial assets over fixed assets), the debt ratio (total debt over assets), and the structure of the firm's debt (supplier debt over total debt). It in addition includes the size of the firm as measured by the number of employees (in logs), dummies for legal status, firm age ( 1 if the firm is over five years old), and the "zombie" status of the firm. All of these firm-level controls come from the last balance sheet and income statement available before the filing.

Despite these many controls, endogeneity remains a potential problem. The conversion of a filing suggests worsening firm financial health that mechanically reduces its chances of survival. We therefore identify the causal effect of RJ conversion on firm survival by drawing on the heterogeneity in Commercial Courts' propensity to convert Sauvegarde cases into RJ, as an instrumental variable.

\section{The instrument}


Our instrument is constructed as follows:

$$
\phi_{i, j, t^{\prime}}=\frac{\# \text { conversion }_{j, t^{\prime}}-1\left(\text { converted }_{i, t^{\prime}}=1\right)}{\# \text { cases }_{j, t^{\prime}}-1}
$$

where $\phi_{i, j, t^{\prime}}$ is the share of Sauvegarde cases converted by Court $j$ in year $t^{\prime}$, excluding the present case $i$. This measure excludes the mechanical relationship that would exist between the instrument for a given case and its conversion decision (Maestas et al. (2013)). To take into account the fact that a significant share of the judges in each Court are replaced each calendar year, $\phi_{i, j, t^{\prime}}$ is estimated by year of judgment $t^{\prime}$. As 2016 filing judgments can take place up to 2018, the instrument covers the period 2010 - 2018. The validity of this instrument relies on a number of assumptions that are discussed below.

The territorially-competent Court of a firm filing for bankruptcy is that which is located in the same geographical area as the firm's headquarters. Thus, the firm does not have a choice over its Court (preventing forum-shopping). Even so, firms may choose their headquarters' location based on the behavior of the Commercial Court; we have no evidence that this is the case. Empirical analyses of firm locations in France, such as Houdebine and Schneider (1997) and Costes (2008), do not mention this possibility, and consider only standard location determinants such as local taxes and subsidies, local policies, and agglomeration economies. In our sample, we can identify only one firm whose change in location (in the three years before filing for Sauvegarde) resulted in a change in its assigned Court.

We next have to make sure that there is no "time-shopping" either. This is unlikely as once a firm faces financial difficulties that are severe enough for a Sauvegarde filing, the time window within which it has to file for Sauvegarde is quite narrow. A firm that waits too long to file may no longer be eligible for Sauvegarde and may thus have to file for RJ. To rule out the possibility of "time-shopping," we can test whether firms' tendency to file for Sauvegarde is negatively correlated with the current or past conversion rates of their assigned Court. The results appear in Table A.1, where the dependent variable is the ratio of Sauvegarde cases to all restructuring cases at the Court $\times$ Year level. There is no significant correlation between current Sauvegarde filings and current or past conversion rates.

We then turn to the firm level, and ask whether a firm's decision to file for Sauvegarde is affected by the Court's propensity to convert Sauvegarde cases. For example, firms may be 
discouraged from filing for Sauvegarde if they know that their Court has a high conversion rate. We test this assumption by looking at the correlation between the probability that a firm will file for Sauvegarde instead of RJ, and the conversion rate of its Court in the current and previous years. The results in Table A.2 again reveal no significant relationship.

We can thus consider Court $\times$ Year assignment as close to random, and, after controlling for time and observable characteristics of the firm, use annual Court conversion rates as a source of exogenous variation in the probability that a given case will be converted. Figure 1 shows the distribution of Court conversion rates, minus the annual mean across all Courts, adjusted and unadjusted for the controls and fixed effects in specification (1). The set of controls does not reduce the standard deviation of the instrument distribution (which is 0.14 , as compared to 0.15 unadjusted) that we will exploit in our model.

The first stage of our instrumental-variable estimation is as follows:

$$
\text { Conversion }_{i, j, t^{\prime}}=\rho+\pi \cdot \phi_{i, j, t^{\prime}}+\gamma_{1} X_{i, t}+\mu_{s, t^{\prime}}+\mu_{j}+\epsilon_{i, j, t^{\prime}}
$$

where Conversion $i, j, t^{\prime}$ is a dummy for firm $i$ being converted to RJ at time $t^{\prime}$ in Court $j$. The coefficient $\pi$ shows the impact of the Commercial Court's propensity $\phi_{i, j, t^{\prime}}$ to convert Sauvegarde to RJ on the probability that a case actually will be converted.

\section{The model}

The second step is estimated as follows:

$$
Y_{i, j, t^{\prime}}=\alpha+\beta \cdot \text { Conversion }_{i, j, t^{\prime}}+\gamma_{1} X_{i, t}+\mu_{s, t^{\prime}}+\mu_{j}+\epsilon_{i, j, t^{\prime}}
$$

where Conversion $n_{i, j, t^{\prime}}$ are the values predicted from the first-stage regression. This equation is similar to equation (1), except that the variation in $\widehat{\text { Conversion }}{ }_{i, j, t^{\prime}}$ comes from the exogenous variation introduced by the Court's tendency to convert. If the instrument is valid, then $\beta$ captures the causal effect of RJ conversion on the firm's probability of debt restructuring. This effect is a local average treatment effect (Angrist et al. (1996)).

Court dummies $\mu_{j}$ appear in equations (3) and (4) to control for unobservable characteristics of the Courts and/or the firms under their jurisdiction. As discussed above, heterogeneity in conversion rates is a combination of heterogeneity between Courts and heterogeneity over time 
within each Court. The use of Court dummies, with the instrument calculated at the Court $\times$ Year level, means that we do not appeal to heterogeneity in conversion practices between Courts: our estimate of the impact of conversion is based only on changes in conversion rates over time within each Court.

\section{Assigned Court vs. Closest Court}

In order to rule out any possibility that the instrument reflects the local economic conditions and not the behavior of the Court, we design an alternative first stage. In this alternative first stage, we exploit the fact that while firms are assigned to a Court depending on their location, given administrative boundaries a significant share of firms (19\%) are geographically closer to a Court that is different from the one to which they are assigned. ${ }^{22}$

Let's consider a dummy $C C$ that equals 1 for firms for which the assigned Court is also the closest one, and 0 otherwise. The first-stage equation we consider is then :

$$
\begin{aligned}
\text { Conversion }_{i, j, t^{\prime}}=\rho & +\pi_{1} \cdot \phi_{i, j, t^{\prime}} \times C C \\
& +\pi_{2} \cdot \phi_{i, j, t^{\prime}} \times(1-C C) \\
& +\pi_{3} \cdot \phi_{i, j^{\prime}, t^{\prime}}^{\prime} \times(1-C C)+\gamma_{1} X_{i, t}+\mu_{s, t^{\prime}}+\mu_{a}+\epsilon_{i, j, t^{\prime}}
\end{aligned}
$$

where $\phi_{i, j, t^{\prime}}$ is the share of other cases converted in year $t^{\prime}$ by Court $j$ to which firm $i$ is assigned, and $\phi_{i, j^{\prime}, t^{\prime}}^{\prime}$ is the analogous figure for the closest Court $j^{\prime}$. We drop the Court-level dummies and introduce Court of Appeal-level dummies $\mu_{a}$. We are interested in the coefficients $\pi_{1}, \pi_{2}$ and $\pi_{3}$. Because there are no Court fixed effects here, $\pi_{1}$ is probably biased as the instrument includes both Court preferences and other local characteristics. $\pi_{2}$ is less likely to be biased, as it is estimated based on firms whose conversion depends on the yearly Court preference for conversion, but much less on other local characteristics. We thus expect $\pi_{1}$ to be larger than $\pi_{2}$. In addition, if the unobservable local characteristics reflected in the instrument are important, we would expect $\pi_{3}$ to be positive and significant. However, if unobservable local characteristics are not reflected in the instrument, we would expect $\pi_{3}$ to be insignificant, that is the chance of being converted would not depend on the conversion rate of the closest Court.

\footnotetext{
${ }^{22}$ For example, consider a firm in the North-East of the Cahors juridiction. This firm will be closer to the Commercial Court in Aurillac than to the one in Cahors to which it is assigned (see Figure 2).
} 
The second step is then as follows:

$$
Y_{i, j, t^{\prime}}=\alpha+\beta \cdot \text { Conversion }_{i, j, t^{\prime}}+\gamma_{1} X_{i, t}+\mu_{s, t^{\prime}}+\mu_{a}+\epsilon_{i, j, t^{\prime}}
$$

\subsection{First-stage results}

The Court conversion rate, as shown in Table 5, is strongly correlated with the probability of RJ conversion. The F-statistic measuring instrument strength is about 26.6, above the threshold of 10 suggested by Staiger and Stock (1997). The coefficient associated with the instrument is statistically significant at the $1 \%$ level and robust to the introduction of multiple controls: the point estimate varies from 0.293 without any control variables other than the Legal Status, Court and Industry $\times$ Year fixed effects (column (1) of Table 5), to 0.265 when all the controls and fixed effects are included (column (3) of Table 5). The latter is our preferred first-stage estimation. The point estimate of 0.265 implies that a one standard-deviation rise $(34.9 \%)$ in the conversion rate increases the probability of being converted by $9.2 \%$. This is much higher than the unconditional propensity of $14.2 \%$.

The results of the alternative first stage that differentiates between closest Court and assigned Court appear in Table6. The first-stage estimate of the impact of the Court's conversion rate is more or less the same as that in Table 5. Notably, in the firms for which the coefficient is not biased, the coefficient $\pi_{2}$ column (2) is 0.265 , the same as the figure reported in Table 5 column (2). Interestingly, as expected, the estimated value of $\pi_{1}$ is slightly higher than $\pi_{2}$, and $\pi_{3}$ is not significant. We can be confident that the sensitivity of Conversion to the instrument (result Table 5 reflects the behavior of the Court rather than local economic conditions.

As pointed out by Angrist et al. (1996), the causal effect of the instrument on the probability of being converted to RJ cannot be generalized to the whole population of Sauvegarde filings. The measured conversion impact ( $\beta$ in equation (44) is only valid for the firms that are sensitive to the Court's conversion propensity: the compliers. Following the analysis in Maestas et al. (2013), as our treatment is binary, the proportion of compliers equals the first-stage coefficient times the range of the instrument (in this case, 1). In our data, $26.5 \%$ of the firms filing for Sauvegarde may be converted to RJ depending only on their Court's propensity to convert. With the average conversion rate being $14.2 \%, 3.8 \%$ of firms filing for Sauvegarde are converted due to this propensity, and $22.7 \%$ are not converted for the same reason. This also implies 
that, regardless of the Court-Year to which they are assigned, $10.4 \%$ of the firms filing for Sauvegarde would always be converted (the always-takers) and $63.1 \%$ would never be converted (the never-takers).

The above analysis holds only under the monotonicity, or no-defiers, assumption: all the sensitive firms must be affected identically by a given Commercial Court (the likelihood of being converted either rises or falls for all firms that are assigned to the same Court). In our setting, sub-samples should have a non-negative first-stage estimate: we carry out this test in Table 7 . We split our sample by industry, age, firm size and financial ratios. The instrument coefficient is positive and significant in all sub-samples and does not vary greatly, providing support for the monotonicity assumption.

\subsection{Testing the Exclusion-Restriction Condition}

As the Court has a role not only in conversion but also in debt renegotiation, we need to check that the exclusion-restriction condition is met. This latter requires that while the Court conversion propensity does indeed affect the firm conversion probability, it has no direct effect on the probability of reaching an agreement with the firm's creditors. It also requires that no omitted variable impact both the conversion rate and the probability of a deal with creditors. In our model, there is a potential risk that the exclusion-restriction condition will not be met: local economic factors may affect both the conversion rate and the probability of reaching a deal with creditors. This will be the case if, with the local economy in a bad state, firms in restructuring are more likely to be liquidated, and Sauvegarde firms are more likely to become insolvent and thus to be converted into RJ (with the reverse argument in the case of a good local economy).

In theory, the exclusion-restriction condition cannot be checked in the data. In our setting, it is however possible to test it in another population of firms that are similar to those considered here: firms that filed directly for RJ. As the Sauvegarde and RJ procedures are very similar, we can assume that the process leading to restructuring a firm's debt is similar in both procedures, and that local economic conditions play the same role regardless of the procedure.

We estimate equation (7), which is the reduced form of our model, on the sample of direct RJ filings.

$$
Y_{i, j, t^{\prime}}=\alpha+\beta \cdot \phi_{i, j, t^{\prime}}+\gamma_{1} X_{i, t}+\mu_{s, t^{\prime}}+\mu_{j}+\epsilon_{i, j, t^{\prime}}
$$


Table 8 shows the results for the sample of all direct RJ filings in column (1) and the subsample of voluntary RJ filers in column (2). Voluntary RJ filers are more similar to Sauvegarde filers, as they are likely to be more pro-active when faced with financial difficulties as compared to RJs that are triggered by the firm's creditors or the Court. We find no statisticallysignificant coefficients here, such that our instrument is uncorrelated with the probability of debt-restructuring in direct RJ filings. This suggests that the chances of reaching an agreement to restructure firm debt are not related to the Court's conversion propensity. We can therefore consider that the exclusion-restriction holds.

\section{$5 \quad$ Main Results and Robustness}

\subsection{The impact of RJ conversion on debt-restructuring}

We now focus on how conversion affects the firm's probability of reaching a debt-restructuring agreement with its creditors.

The second-stage estimates (equation (4)) appear in column (2) of Table 9 and the OLS estimates in column (1). The OLS estimates suggest that conversion is associated with a fall in the debt-restructuring probability of approximately 56 percentage points; in our IV estimates conversion results in a 49.5 percentage-point fall in the debt-restructuring probability. As such, accounting for selection produces a larger estimate of the effect of RJ conversion on the probability of debt restructuring. Older and larger firms are more likely to reach an agreement with their creditors. As far as the balance sheet is concerned, a higher fixed-asset ratio is associated with a better probability of reaching an agreement, and a higher debt is associated with lower chances of restructuring. "Zombie" status produces a lower probability of debtrestructuring.

Columns (3) of Table 9 present the corresponding second-stage estimates when differentiating between the closest Court and the assigned Court. The impact of RJ conversion is about the same as that in column (2), reducing the chance of reaching a deal by about $52 \%$.

Based on these results, we can conclude that for firms that are on the margin of being converted, conversion significantly reduces their chances of reaching a debt-restructuring agreement. 


\subsection{Evidence supporting the role of less sophisticated stakeholders}

How to explain the fact that the conversion from Sauvegarde to RJ significantly reduces the chances of restructuring even after controlling for selection bias (i.e. the fact that converted firms are amongst the weakest one)? Our suggested explanation is that conversion triggers a change in behavior in at least some stakeholders of the firm. It is unlikely that conversion adds much information to informed stakeholders and triggers a change in their behavior. Conversion, however, can deliver additional information to less informed stakeholders, like clients, who may have a binary view of the situation of the firm.

To support the idea that the impact of conversion on the probability of restructuring comes from the behavior (or the change in behavior) of "less informed stakeholders," we design additional empirical tests. These tests are based on the splitting of our sample into sub-samples of firms according to some rough measures regarding the type of clients (informed/less informed) that firms are dealing with. If one considers that final customers are less aware than other businesses of the meaning of Sauvegarde, firms whose products are mainly aimed at customers (as opposed to other businesses) will suffer more from conversion than B-to-B firms. In the same vein, one can expect that conversion from Sauvegarde to RJ will have a smaller impact on firms with foreign clients, as foreign clients are less likely to be aware of the difference between the two bankruptcy procedures.

To test these conjectures, we estimate the equations (3) and (4) on each set of subsamples. We use the 2-digit SIV codes to separate B-to-B firms from B-to-C ones. More precisely, using national accounts, for each product we calculate the ratio of household expenditures (investment and final consumption) to that of businesses (intermediate consumption, investment). According to this methodology, $46 \%$ of the firms in our sample are in sectors that produce mainly for households, and $54 \%$ are in sectors producing mainly for other businesses.

To identify firms with foreign clients we use the same method, relying on national accounts. With this methodology, $33 \%$ of the firms in our sample are in sectors with high level of exports, and $77 \%$ in sectors producing mainly for domestic clients. The size of the sample of firms in exporting sectors is small, which might reduce our ability to estimate the impact of conversion on debt restructuring. We thus implement a second approach that splits the final sample into two sub-samples, according to the ratio of foreign sales to domestic sales in the income statement 
of the firm, compared to its median value over the sample. By construction, while the sizes of the two sub-samples are the same, there is however a potential endogeneity.

Results are shown in Table 10 where we compare the IV estimates of each set of subsamples. We would expect firms in B-to-B sectors to be less impacted by conversion, and the corresponding IV estimate should be smaller for these firms than that on firms in B-to-C sectors. This is indeed the case, with an IV estimate at -0.350 for B-to-B and -0.661 for B-to-C. Also, the B-to-B coefficient is significant at the $10 \%$ level only. We also expect firms in exporting sectors to be less impacted by conversion, as foreign clients are probably less aware of the subtleties of French bankruptcy laws. The IV estimate is indeed smaller and not significantly different from 0 for these firms, while it is significant for firms in non-exporting sectors. However, one cannot rule out that the fact that the IV estimates are not significant comes from the small size of the sample of firms in the non-exporting sectors. When the sample of firms is split according to the median of firms' ratio of domestic sales to foreign sales, the IV coefficients are significant in the two sub-samples, but they are stronger and more significant for less export-reliant firms.

Results shown in this section are consistent with the hypothesis that the impact of conversion on restructuring chances is driven by the behavior of less informed stakeholders. They are not sufficient to prove that this is the case. The results can nevertheless support the intuition that the behavior of less informed stakeholders matter.

\subsection{Robustness tests}

\section{Using different samples}

Various robustness checks have been carried out to ensure the validity of our results. We have re-estimated our equations (3) and (4) based on three slightly different samples.

A concern could be that our results are driven by small Courts that deal with only a small number of Sauvegarde cases each year. Time variation in the conversion rates for small Courts is indeed higher than that in larger Courts. To check that this does not affect our results, we rerun our estimations considering only the cases assigned to the largest $75 \%$ of Courts (in terms of Sauvegarde openings over the 2010 - 2016 period). This leaves us with 4,750 Sauvegarde cases, of which $16.1 \%$ are converted into RJ. The results are shown in columns (5) and (6) of Table 11 the first-stage results are very similar to those above, and the impact of conversion on the chances of reaching a debt-restructuring deal is around $-40 \%$. 


\section{Placebo model}

We next carry out a placebo test to rule out the possibility that our results here only come about by chance. We substitute our instrument with a placebo instrument that randomly assigns the values of share of other cases converted within the sample. We replicate our preferred specification (column (2) of Table 5) with this randomly-assigned instrument 10,000 times. Similar results in these regressions would call into question the validity of our identification strategy. Figure 3 plots the distribution of the 10,000 placebo regression coefficients $\pi$, and the main statistics of the resulting distribution. On average, the coefficient on the randomlyassigned instrument is zero. The actual coefficient of share of other cases converted (0.265) is about ten standard deviations (0.0272) above the mean (0.000), and far above the distribution's maximum estimate (0.0929). While these results do not prove that our instrument is valid, they do alleviate concerns that our main results only reflect chance.

\subsection{The impact of RJ conversion on survival rates}

\section{Survival rates at 2 and 4 years conditional to debt-restructuring agreement}

Reaching a debt-restructuring agreement with creditors is not the end of the story for the firm and its creditors. As discussed above, the typical restructuring agreement is a mix of debtrescheduling for up to 10 years and debt forgiveness. Unlike the case in the United States, creditors (which in France are mainly banks and suppliers) rarely exchange debt for control over the firm, and their claims are not covered by the issuance of new debt. Existing creditors are thus greatly interested in the survival of the firm after a debt agreement is reached.

We here want to see whether RJ conversion affects survival after an agreement with creditors. As above, conversion is endogenous, which prevents us from estimating a hazard model; we thus rely on 2SLS linear models. We use the same instrument as before.

Table 12 shows the impact of RJ conversion on firm survival after debt-restructuring. As we consider survival up to May 2020, we look at the two-year survival rate of the 3,833 firms that obtained a restructuring deal before May 2018, and the four-year survival rate of the 3,053 firms with a restructuring deal before May 2016. We report OLS and IV-2SLS second-stage estimates, which both convey the same message: once the firm reaches an agreement, its survival is not affected by its filing having been converted. This holds for both the two- and four-year 
survival rates. This could be interpreted to mean that any negative impact associated with RJ disappears once the firm has been granted a second chance.

\section{Unconditional survival rate at 3 and 5 years after bankruptcy filing}

There are however two possible interpretations of the absence of impact of conversion on the survival of firms that have restructured their debt, as described in the previous section. A first interpretation is that once the firm has restructured its debt, the loss of reputation associated with the conversion to RJ disappears, and the converted firms do as well as the firms that remained in Sauvegarde. The second interpretation is that some of the firms that remained in Sauvegarde and obtained a debt-restructuring agreement were on the margin of being converted. These firms, even though they managed to restructure their debt, do not survive for long afterwards. This amounts to saying that a part of the non-converted firms do as badly as the converted ones. One way to test this is to look at whether the survival rate of firms entering Sauvegarde - whether or not they restructure their debt - depends on conversion. If the unconditional survival rate does not depend on conversion, the conclusion will be that non-converted firms at the margin of being converted will do just as badly as those that have been converted. Conversion to RJ would then ultimately only be a short-term event with no long-term impact on the firm. If, on the contrary, the unconditional survival rate depends on conversion, the effect of conversion is potentially significant, not only for restructuring, but also for the longer-term survival of the firm.

We thus test whether conversion to RJ affects the survival of firms, independent of reaching an agreement with their creditors. As previously, conversion is endogenous and we use the same instrument as before. Results in Table 12 show that the unconditional survival at three and five years after a firm files for bankruptcy significantly depends on whether it has been converted or not. These results support our hypothesis that the behavior of stakeholders is a determining factor in the survival of the firms on a short and long-term horizon.

\subsection{Economic Importance and External Validity}

We can convert the reduction by $50 \mathrm{pp}$ in the probability of reaching a debt agreement after conversion (see Table 11 column (4)) into an indirect cost of RJ. According to Blazy et al. (2018), recovery rates in France in continuation are around $73 \%$ for unsecured creditors and 
$75 \%$ for secured creditors, with the analogous figures in liquidation being $5 \%$ and $35 \%$. In our sample, the average firm entering Sauvegarde has a debt to asset ratio of $80 \%$ (see Table 3), $75 \%$ of which is secured 23 These numbers lead to indirect costs of $20 \%$ of the firm's book assets if shareholders lose everything, in both continuation and liquidation. This estimate is towards the top end of those in the literature, which suggests average indirect bankruptcy costs of between $10 \%$ and $20 \%$ of firm value. 24

There are around 1,000 Sauvegarde filings per year, around $14 \%$ of which are converted to RJ. According to the first-stage results, $26 \%$ of Sauvegarde filings are at the margin of being converted. This means that on average 36.4 firms per year $(1,000 \times 26 \% \times 14 \%)$ are converted to RJ only because of the Court's preferences that year. For these 36 firms, reaching a debt-restructuring deal with their creditors will be much harder than if, all else being equal, they had not been converted to RJ by their Court. The aggregate economic impact of these findings could be small if the effect we measure concerns only the Sauvegarde filings. However, if these indirect bankruptcy costs apply to the 15,000 firms that file for RJ each year, the overall economic impact could be large.

\section{Conclusion}

Using a novel and almost exhaustive data set of Court-supervised bankruptcy procedures in France, this paper has analyzed the effect of being converted from a preventive procedure (Sauvegarde) into the regular bankruptcy procedure (RJ). Both bankruptcy procedures are public and Court-supervised. We use heterogeneity in Commercial Court conversion rates as an instrument for conversion, and show that, for firms at the margin of being converted, conversion reduces the probability of reaching a deal with creditors by around 50 percentage points. This corresponds to indirect costs of bankruptcy of up to $20 \%$ of book assets. As the legal provisions differ little between the two procedures, we attribute this to indirect costs associated with the bad track-record of RJ. The track-record of RJ is so bad that the stakeholders of firms converted into RJ change their behavior toward the firm. This behavior, based on a prophesy of failure, is self-fulfilling.

The rationale for introducing the Sauvegarde procedure into French commercial law was

\footnotetext{
${ }^{23}$ We hypothesize that suppliers are unsecured creditors.

${ }^{24}$ See for example Hotchkiss et al. (2008) and Bris et al. (2006).
} 
to offer a distinct Court-supervised debt-restructuring procedure to fragile firms that were not yet insolvent. Our results support this policy choice, rather than the simple extension of RJ to these firms. The Sauvegarde procedure allows stakeholders to differentiate firms from the average firm filing for bankruptcy, thus improving the chance of keeping the firm as a going concern. This benefits both secured and unsecured creditors. The 2019 EU directive proposed the introduction of a preventive restructuring procedure in all Member States that only noninsolvent firms could access. Adding a new preventive procedure will avoid its contamination by the regular debt-restructuring procedure, notably in countries where their track-records are poor. For example, García-Posada Gómez and Vegas Sánchez (2018) report that only around $7 \%$ of firms manage to restructure their debt in Spain, and Franks and Loranth (2013) mention that it is about $20 \%$ in Hungary. Other countries, therefore, should consider drawing on French experience. 


\section{References}

Müge Adalet McGowan, Dan Andrews, and Valentine Millot. Insolvency Regimes, Zombie Firms and Capital Reallocation. OECD Working Paper, (ECO/WKP(2017)31):54, June 2017.

Heitor Almeida and Thomas Philippon. The Risk-Adjusted Cost of Financial Distress. The Journal of Finance, 62(6):2557-2586, December 2007.

Edward I. Altman. A Further Empirical Investigation of the Bankruptcy Cost Question. The Journal of Finance, 39(4):1067-1089, September 1984.

Gregor Andrade and Steven N. Kaplan. How Costly is Financial (Not Economic) Distress? Evidence from Highly Leveraged Transactions that Became Distressed. The Journal of Finance, 53(5):1443-1493, October 1998.

Joshua D. Angrist and Jörn-Steffen Pischke. Mostly Harmless Econometrics: An Empiricist's Companion. Princeton: Princeton University Press, 2008.

Joshua D. Angrist, Guido W. Imbens, and Donald B. Rubin. Identification of Causal Effects Using Instrumental Variables. Journal of the American Statistical Association, 91(434):444455, June 1996.

Shai Bernstein, Emanuele Colonnelli, Xavier Giroud, and Benjamin Iverson. Bankruptcy Spillovers. Journal of Financial Economics, 133(3):608-633, September 2019a.

Shai Bernstein, Emanuele Colonnelli, and Ben Iverson. Asset Allocation in Bankruptcy. The Journal of Finance, 74(1):5-53, February 2019b.

Régis Blazy, Joël Petey, and Laurent Weill. Serving the creditors after insolvency filings: from value creation to value distribution. European Journal of Law and Economics, 45(2):331-375, April 2018.

Severin Borenstein and Nancy L Rose. Bankruptcy and Pricing Behavior in U.S. Airline Markets. The American Economic Review, 85(2):397-402, 1995.

Arturo Bris, Ivo Welch, and Ning Zhu. The Costs of Bankruptcy: Chapter 7 Liquidation versus Chapter 11 Reorganization. The Journal of Finance, 61(3):1253-1303, June 2006. 
Federico Ciliberto and Carola Schenone. Bankruptcy and Product-Market Competition: Evidence From the Airline Industry. International Journal of Industrial Organization, 30(6): 564-577, Nov 2012.

Nicolas Costes. Choix de localisation des entreprises, intervention publique et efficacité urbaine : Une analyse théorique et empirique de la réglementation des choix de localisation des activités de bureau en Île-de-France. Economies et finances. Université Panthéon-Sorbonne - Paris I, February 2008.

Sergei A. Davydenko, Ilya A. Strebulaev, and Xiaofei Zhao. A Market-Based Study of the Cost of Default. Review of Financial Studies, 25(10):2959-2999, October 2012.

Stéphane Esquerré. Court Structure and Legal Efficiency, the Case of french Échevinage in Bankruptcy Courts. September 2019.

Julian Franks and Gyongyi Loranth. A Study of Bankruptcy Costs and the Allocation of Control. Review of Finance, 18:961-997, June 2013.

Miguel García-Posada Gómez and Raquel Vegas Sánchez. Bankruptcy reforms in the midst of the Great Recession: The Spanish experience. International Review of Law and Economics, 55:71-95, September 2018.

Ali Hortaçsu, Gregor Matvos, Chad Syverson, and Sriram Venkataraman. Indirect costs of financial distress in durable goods industries: The case of auto manufacturers. Review of Financial Studies, 26(5):1248-1290, 2013.

Edith S. Hotchkiss, Kose John, Karin S. Thorburn, and Robert M. Mooradian. Bankruptcy and the Resolution of Financial Distress. SSRN Electronic Journal, 2008.

Michel Houdebine and Jean-Luc Schneider. Mesurer l'influence de la fiscalité sur la localisation des entreprises. Économie et prévision, May 1997.

Benjamin Iverson, Joshua Madsen, Wei Wang, and Qiping Xu. Learning by Doing: Evidence from Bankruptcy Judges. July 2019.

Nicole Maestas, Kathleen J Mullen, and Alexander Strand. Does Disability Insurance Receipt 
Discourage Work? Using Examiner Assignment to Estimate Causal Effects of SSDI Receipt. American Economic Review, 103(5):1797-1829, August 2013.

Stephen Morris and Hyun Song Shin. Coordination Risk and the Price of Debt. European Economic Review, 48(1):133-153, Feb 2004.

Tim C. Opler and Sheridan Titman. Financial Distress and Corporate Performance. The Journal of Finance, 49(3):1015-1040, July 1994.

Gordon Phillips and Giorgo Sertsios. How Do Firm Financial Conditions Affect Product Quality and Pricing? Management Science, 59(8):1764-1782, Aug 2013.

Guillaume Plantin, David Thesmar, and Jean Tirole. Les enjeux économiques du droit des faillites. Notes du conseil d'analyse économique, 7(7):1, June 2013.

Douglas Staiger and James H Stock. Instrumental Variables Regression with Weak Instruments. Econometrica, 65(3):557-586, May 1997. 
Figure 1: Commercial Courts' average conversion rates over the 2010 - 2018 period

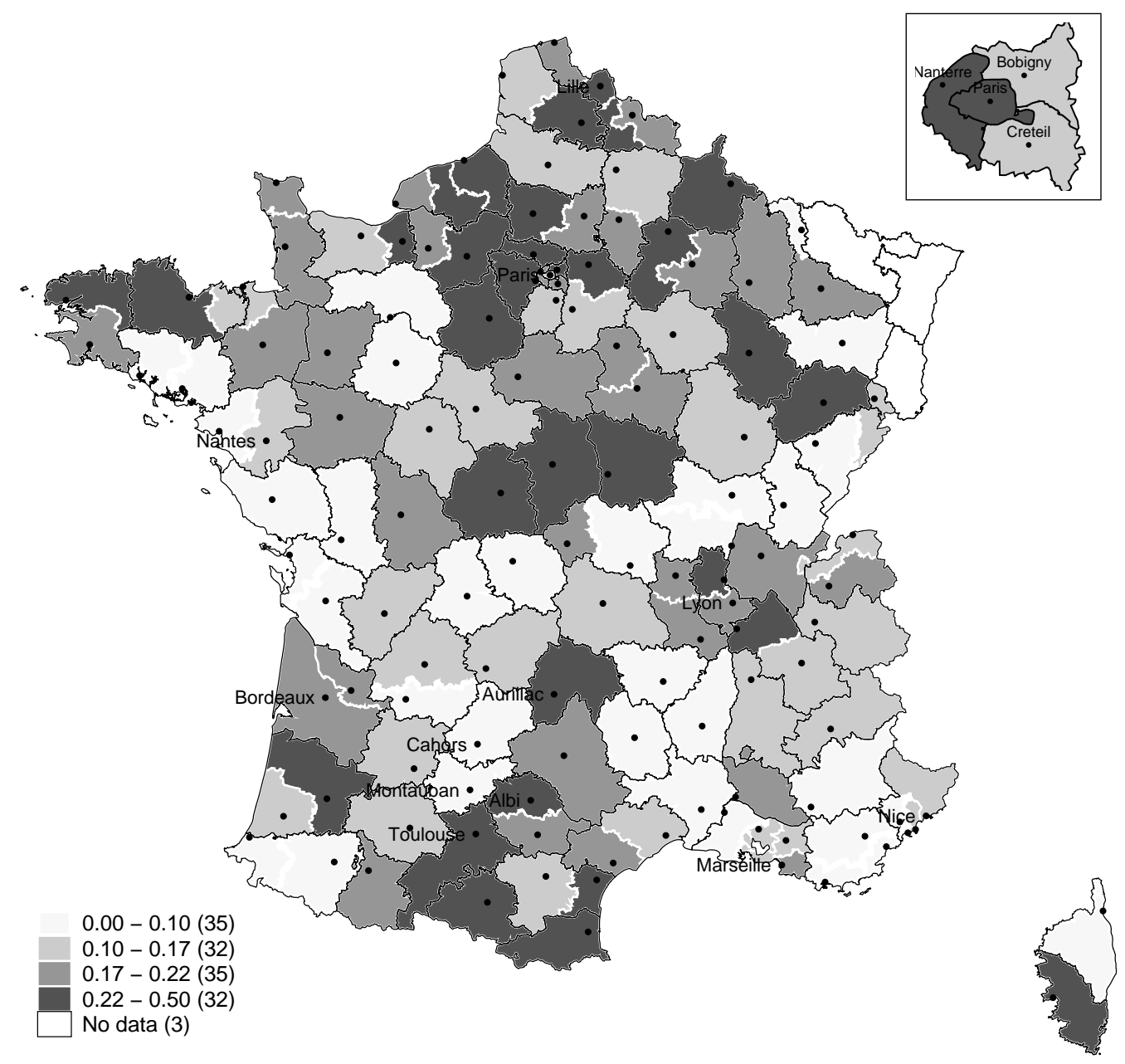

The jurisdictions of French Commercial Courts are based on Département boundaries. Some Départements have two or more Commercial Courts. Figure 2 maps these jurisdictions: black lines delimit Département boundaries and white lines those of jurisdictions within a Département. Black dots represents the location of Commercial Courts. The three Département of Moselle, Haut-Rhin and Bas-Rhin are excluded (see footnote 20). The upper-right part of the figure zooms in on the region of Paris. Figure 2 shows the average conversion rates of Sauvegarde to RJ in Commercial Courts by jurisdiction over the 2010 - 2018 period. 
Figure 2: The distribution of Court deviations from the mean initial conversion rate

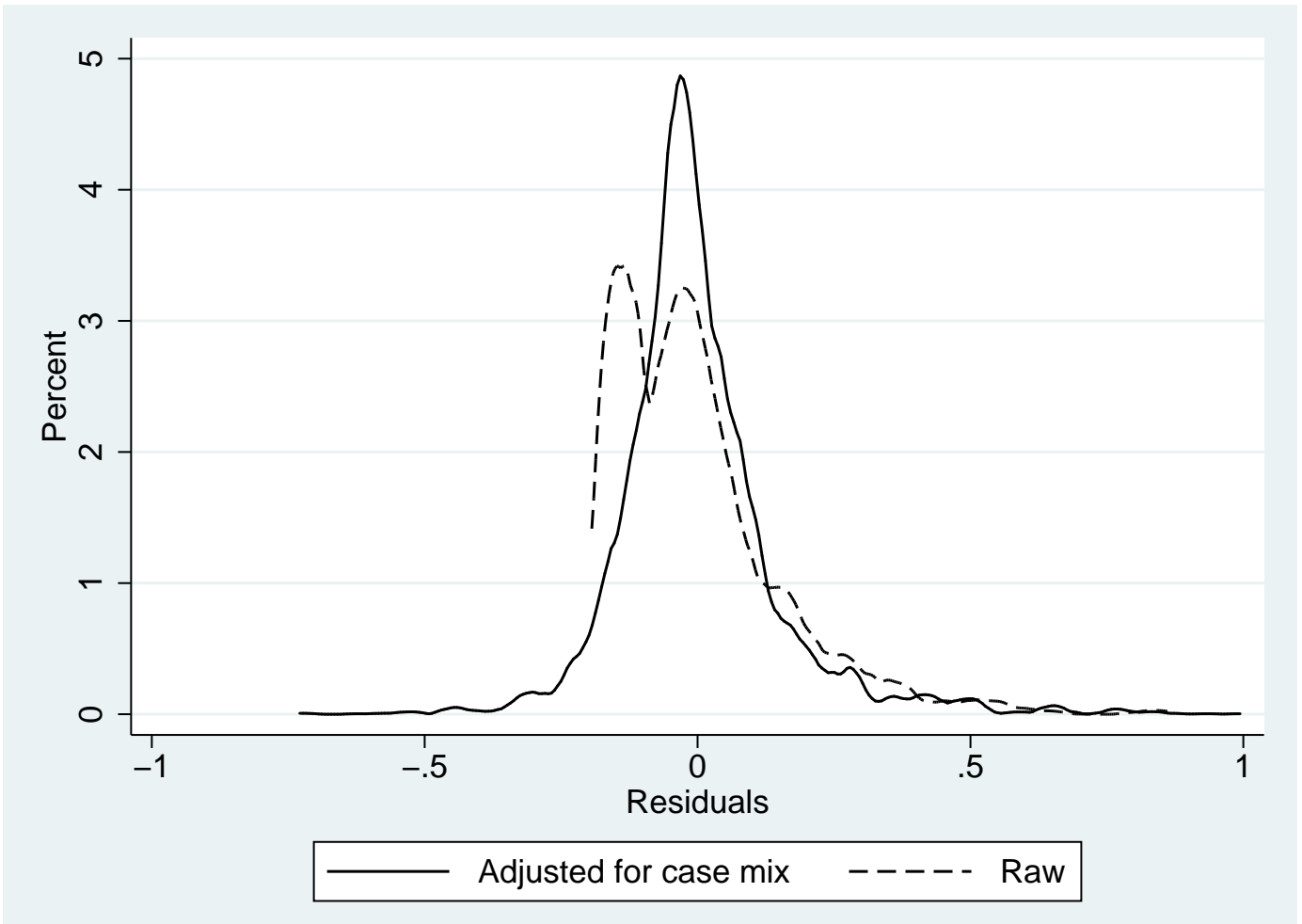

The raw distribution reflects the difference between the Court's conversion rate and the unadjusted annual average conversion rate; the adjusted distribution is the difference between the Court's conversion rate and the annual average conversion rate adjusted for all of the controls and fixed effects, as in column (2) of Table 5 . 
Figure 3: Placebo test

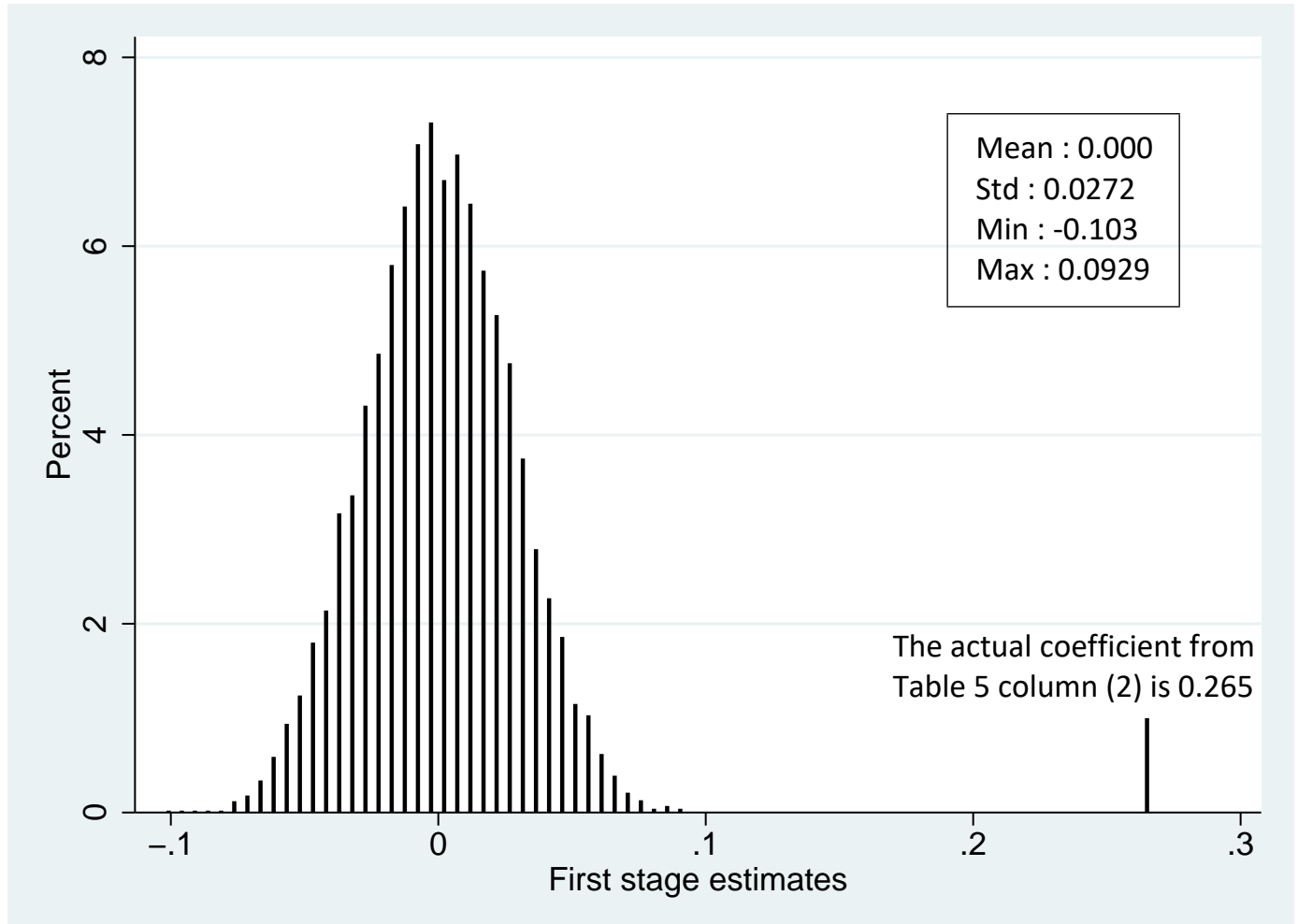

This figure shows the histogram of the coefficient on the share of other cases converted from 10,000 placebo regressions where the instrument share of other cases converted was randomly assigned within the sample. The regressions contain the full set of controls and fixed effects from column 2 of Table 5 . 
Table 1: Comparison of the Sauvegarde and RJ procedures

\begin{tabular}{lll}
\hline & \multicolumn{1}{c}{ Sauvegarde } & \multicolumn{1}{c}{ RJ } \\
\hline $\begin{array}{l}\text { Conditions to start } \\
\text { the procedure }\end{array}$ & $\begin{array}{l}\text { The firm is not insolvent and can } \\
\text { prove it is facing severe financial } \\
\text { difficulties }\end{array}$ & $\begin{array}{l}\text { The firm is insolvent (short-term } \\
\text { financial obligations not covered } \\
\text { by liquid assets) }\end{array}$ \\
\hline $\begin{array}{l}\text { Who can start } \\
\text { the procedure? }\end{array}$ & The debtor only & $\begin{array}{l}\text { Once insolvent, the debtor must } \\
\text { start the procedure within } \\
\text { days. Its creditors or the Court }\end{array}$ \\
& & $\begin{array}{l}\text { can trigger the procedure } \\
\text { if the debtor does not }\end{array}$ \\
\hline $\begin{array}{l}\text { Is Court approval } \\
\text { needed to start the } \\
\text { procedure? }\end{array}$ & $\begin{array}{l}\text { YES } \\
\text { The Court allows the opening } \\
\text { of the procedure after checking } \\
\text { that the firm: } \\
\text { (i) is not insolvent } \\
\text { (ii) is facing severe financial } \\
\text { difficulties }\end{array}$ & NO \\
&
\end{tabular}

\section{Role of the Court}

at the onset of the procedure
- Appoints a Receiver

- Appoints an Administrator for large firms (the debtor can suggest an administrator)
- Appoints a Receiver

- Appoints an Administrator

\begin{tabular}{|c|c|c|}
\hline Observation period & \multicolumn{2}{|c|}{6 months twice-renewable } \\
\hline $\begin{array}{l}\text { Protection of the debtor } \\
\text { from its creditors during } \\
\text { the observation period }\end{array}$ & \multicolumn{2}{|r|}{ YES } \\
\hline $\begin{array}{l}\text { Grace period on interest } \\
\text { and principal payments }\end{array}$ & \multicolumn{2}{|r|}{ YES } \\
\hline Role of the Receiver & \multicolumn{2}{|c|}{ Establishes a comprehensive list of the firm's debts } \\
\hline Role of the Administrator & $\begin{array}{l}\text { Assists the firm management } \\
\text { in most decisions }\end{array}$ & Makes most decisions \\
\hline Access to loan for wage arrears & NO & YES \\
\hline Debt-restructuring plan & \multicolumn{2}{|c|}{ Negotiated with creditors by the debtor and the Administrator } \\
\hline Creditor committees & \multicolumn{2}{|c|}{ YES for large firms } \\
\hline Possible outcomes & $\begin{array}{l}\text { - Restructuring } \\
\text { - Conversion to RJ } \\
\text { - Liquidation }\end{array}$ & $\begin{array}{ll}\text { - } & \text { Restructuring } \\
\text { - Liquidation }\end{array}$ \\
\hline
\end{tabular}


Table 2: Breakdown per year of filing

\begin{tabular}{cccc}
\hline \hline $\begin{array}{c}\text { Year of } \\
\text { filing }\end{array}$ & $\begin{array}{c}\text { Number of } \\
\text { Sauvegarde filings }\end{array}$ & $\begin{array}{c}\text { Share of Sauvegarde } \\
\text { cases converted to RJ }\end{array}$ & $\begin{array}{c}\text { Share of } \\
\text { Sauvegarde filings }\end{array}$ \\
\hline 2010 & 691 & 0.156 & 0.116 \\
2011 & 737 & 0.183 & 0.114 \\
2012 & 844 & 0.150 & 0.113 \\
2013 & 935 & 0.139 & 0.128 \\
2014 & 900 & 0.124 & 0.133 \\
2015 & 868 & 0.105 & 0.123 \\
2016 & 703 & 0.145 & 0.107 \\
\hline Total & 5,678 & 0.142 & 0.120 \\
\hline \hline
\end{tabular}

Table 2 shows the number of Sauvegarde entries over the 2010 - 2016 period, the ratio of Sauvegarde cases over all restructuring cases (Sauvegarde and direct RJ), and the share of Sauvegarde cases converted by year of filing. For instance, our analysis sample contains 737 firms that filed for Sauvegarde in 2010, $15.6 \%$ of which were subsequently converted into RJ. 

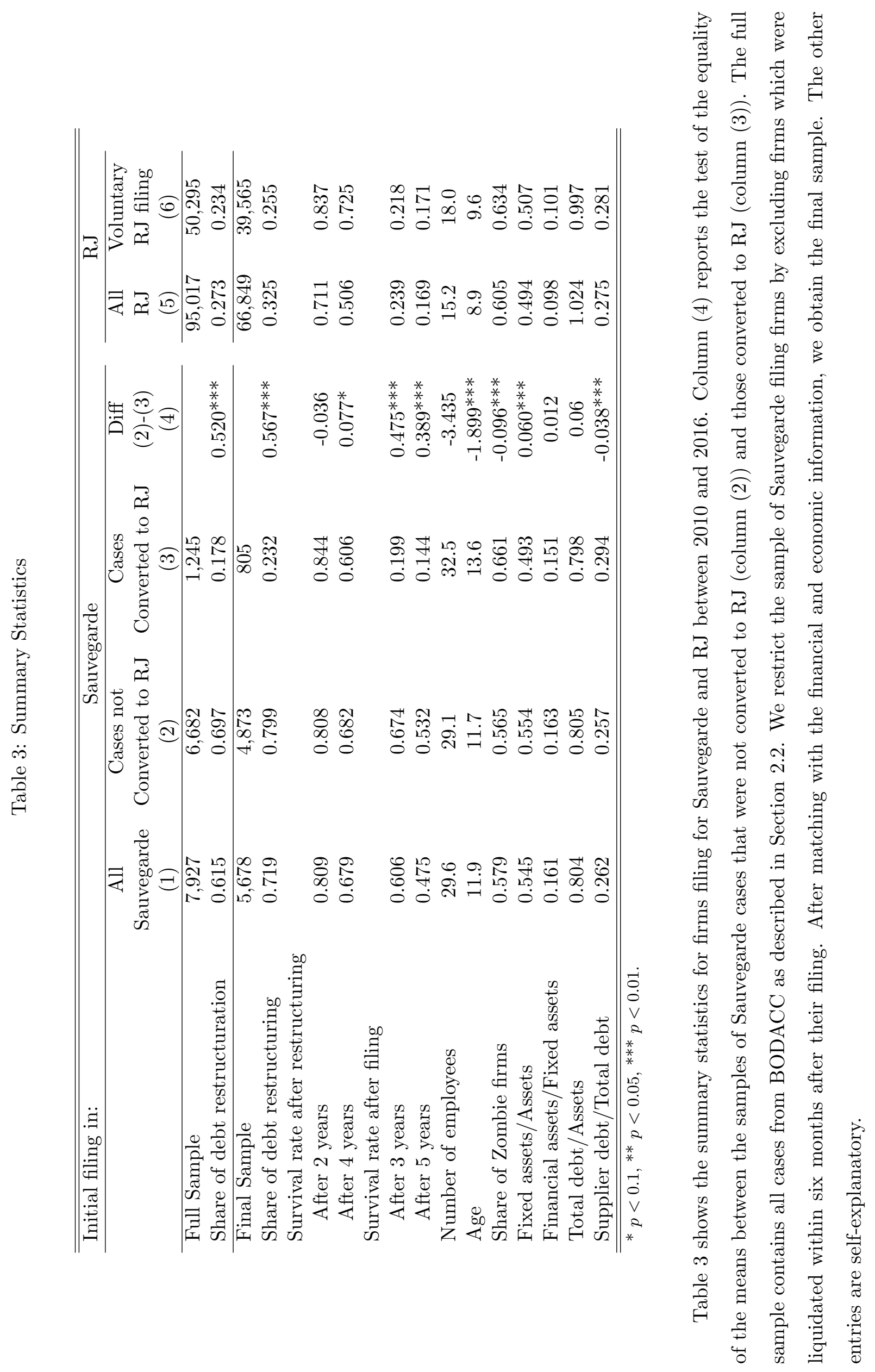
Table 4: Court Heterogeneity

\begin{tabular}{lcrrrrr}
\hline \hline & $\begin{array}{c}\text { Number } \\
\text { of Courts } \\
\end{array}$ & \multicolumn{1}{c}{$\begin{array}{c}\text { Mean } \\
(1)\end{array}$} & $\begin{array}{c}\text { Median } \\
(3)\end{array}$ & $\begin{array}{r}\text { Deviation } \\
(4)\end{array}$ & $\begin{array}{c}\text { Min. } \\
(5)\end{array}$ & $\begin{array}{c}\text { Max. } \\
(6)\end{array}$ \\
\hline Number of judges & 134 & 24.5 & 19.5 & 19.2 & 9 & 180 \\
Number of filings & 134 & 2414.4 & $1,681.0$ & $2,473.7$ & 273 & 19,954 \\
$\quad$ Sauvegarde & 134 & 59.2 & 41.0 & 53.5 & 4 & 308 \\
$\quad$ RJ & 134 & 709.2 & 546.5 & 542.5 & 74 & 3,079 \\
$\quad$ Liquidation & 134 & $1,646.1$ & $1,065.5$ & $2,013.4$ & 191 & 16,982 \\
& & & & & & \\
Share of direct liquidations & 134 & 0.668 & 0.665 & 0.069 & 0.461 & 0.897 \\
Share of Sauvegarde filings & 134 & 0.081 & 0.066 & 0.052 & 0.013 & 0.326 \\
Share of cases converted & 134 & 0.170 & 0.165 & 0.086 & 0.000 & 0.500 \\
Share of debt restructuring & & & & & & \\
$\quad \begin{array}{l}\text { in Sauvegarde } \\
\quad \text { in RJ }\end{array}$ & 134 & 0.579 & 0.589 & 0.117 & 0.200 & 0.929 \\
\hline \hline
\end{tabular}

Table 4 shows the summary statistics for the 134 French Commercial Courts over the 2010 - 2018 period. The share of direct liquidations is the number of direct liquidations over the number of direct liquidations and direct RJs. The share of Sauvegarde filings is the number of Sauvegarde filings over the number of Sauvegarde and direct RJ filings. The share of cases converted is the number of Sauvegarde filings converted by the Court over the total number of Sauvegarde filings. 
Table 5: First Stage

\begin{tabular}{|c|c|c|}
\hline \multirow{2}{*}{ Dependent variable: } & \multicolumn{2}{|c|}{ Conversion to RJ } \\
\hline & (1) & $(2)$ \\
\hline Share of other cases converted & $\begin{array}{c}0.293^{* * *} \\
(5.59)\end{array}$ & $\begin{array}{c}0.265^{* * *} \\
(5.16)\end{array}$ \\
\hline Ln(employees) & & $\begin{array}{c}0.0195^{* * *} \\
(4.57)\end{array}$ \\
\hline $\operatorname{Age}(>5$ years old $)$ & & $\begin{array}{c}-0.0196^{*} \\
(-1.96)\end{array}$ \\
\hline Zombies & & $\begin{array}{c}0.0179^{*} \\
(1.85)\end{array}$ \\
\hline Fixed asset/asset & & $\begin{array}{c}-0.0127 \\
(-0.67)\end{array}$ \\
\hline Financial asset/fixed asset & & $\begin{array}{c}0.0102 \\
(0.61)\end{array}$ \\
\hline Total debt/asset & & $\begin{array}{c}0.00317 \\
(0.40)\end{array}$ \\
\hline Supplier debt/debt & & $\begin{array}{c}0.0185 \\
(0.63)\end{array}$ \\
\hline Legal-status dummies & Yes & Yes \\
\hline Court fixed effects & Yes & Yes \\
\hline Industry $\times$ Year-of-judgment fixed effects & Yes & Yes \\
\hline Observations & 5,678 & 5,678 \\
\hline Adjusted R-squared & 0.063 & 0.044 \\
\hline F-statistic for instrument & 31.234 & 26.620 \\
\hline
\end{tabular}

Table 5 shows the results from the first-stage regressions. The dependent variable is a dummy for the firm being converted to RJ, and the instrument is the share of cases converted by the Commercial Court every year, excluding the current case. The model is robust to the introduction of firm control variables (column (2)). All specifications contain 134 Commercial Court fixed effects, industry $\times$ year-of-judgment fixed effects, and legal-status dummies. The standard errors are clustered at the Court-year of judgment level. 
Table 6: First Stage - Assigned Court vs. Closest Court

\begin{tabular}{lcc}
\hline \hline Dependent variable: & \multicolumn{2}{c}{ Conversion to RJ } \\
& $(1)$ & $(2)$ \\
\hline Share of other cases converted of assigned Court $\times$ CC & $0.367^{* * *}$ & $0.362^{* * *}$ \\
& $(7.42)$ & $(7.46)$ \\
Share of other cases converted of assigned Court $\times(1-\mathrm{CC})$ & $0.263^{* * *}$ & $0.265^{* * *}$ \\
& $(3.48)$ & $(3.52)$ \\
& -0.0700 & -0.0719 \\
Share of cases converted of closest Court $\times(1-\mathrm{CC})$ & $(-0.51)$ & $(-0.53)$ \\
& & \\
& No & Yes \\
All control variables & Yes & Yes \\
\hline Court fixed effects ${ }^{\star}$ & Yes & Yes \\
Industry $\times$ Year-of-judgment fixed effects & 5,678 & 5,678 \\
& 0.072 & 0.076 \\
Observations & 19.45 & 19.70 \\
Adjusted R-squared & & \\
F-statistic for instrument & & \\
\hline \hline$t$ statistics in parentheses. & & \\
${ }^{*} p<0.1,{ }^{* *} p<0.05,{ }^{* * *} p<0.01$. & & \\
${ }^{*}$ This specification includes Court of Appeal fixed effects. & &
\end{tabular}

We exploit the fact that, due to administrative boundaries, a significant share of firms are not assigned to their closest Court. $C C$ is a dummy for the firm being assigned to its closest Court. We introduce column (2) of Table 6 firm-level control variables, as in Table 5 column (2). All specifications contain Court of Appeal fixed effects and industry $\times$ year-of-judgment fixed effects. Standard errors are clustered at the Court-year of judgment level. 
Table 7: First-Stage Heterogeneity

\begin{tabular}{|c|c|c|c|c|c|c|}
\hline & $\begin{array}{c}\text { Number of } \\
\text { Observation } \\
(1)\end{array}$ & $\begin{array}{c}\text { Percent } \\
\text { Converted } \\
(2)\end{array}$ & $\begin{array}{c}\text { Coefficient on } \\
\text { Share converted } \\
(3)\end{array}$ & $\begin{array}{l}\text { T-stat } \\
(4)\end{array}$ & $\begin{array}{c}\text { F-stat } \\
(5)\end{array}$ & $\begin{array}{c}\text { Fraction of } \\
\text { always takers } \\
(6)\end{array}$ \\
\hline Full Sample & 5,678 & 0.127 & $0.222^{* * *}$ & 5.0 & 26.6 & 0.099 \\
\hline \multicolumn{7}{|l|}{ Employees } \\
\hline 0-9 & 2,966 & 0.098 & $0.205^{* * *}$ & 3.6 & 13.2 & 0.078 \\
\hline $1-50$ & 2,134 & 0.185 & $0.303^{* * *}$ & 4.5 & 20.4 & 0.129 \\
\hline$>50$ & 578 & 0.206 & $0.356^{* *}$ & 2.3 & 20.4 & 0.133 \\
\hline \multicolumn{7}{|l|}{ Industry } \\
\hline $\begin{array}{l}\text { Construction } \\
\text { Wholesale and }\end{array}$ & 780 & 0.171 & $0.385^{* * *}$ & 3.4 & 11.7 & 0.105 \\
\hline Retail Trade & 1,504 & 0.126 & $0.360^{* * *}$ & 4.3 & 18.7 & 0.080 \\
\hline Services & 2,440 & 0.117 & $0.242^{* * *}$ & 3.2 & 10.5 & 0.089 \\
\hline Other & 954 & 0.208 & $0.308^{* * *}$ & 2.6 & 6.8 & 0.144 \\
\hline \multicolumn{7}{|l|}{ Age } \\
\hline 5 years old or less & 2,223 & 0.135 & $0.303^{* * *}$ & 4.1 & 16.6 & 0.094 \\
\hline Over 5 years old & 3,455 & 0.146 & $0.228^{* * *}$ & 4.0 & 16.1 & 0.113 \\
\hline \multicolumn{7}{|l|}{ Zombie firm } \\
\hline No & 2,393 & 0.114 & $0.237^{* * *}$ & 3.7 & 13.7 & 0.087 \\
\hline Yes & 3,285 & 0.162 & $0.245^{* * *}$ & 3.9 & 15.5 & 0.122 \\
\hline \multicolumn{7}{|l|}{ Fixed assets/assets } \\
\hline Below median & 2,839 & 0.163 & $0.289^{* * *}$ & 4.8 & 23.3 & 0.116 \\
\hline Above median & 2,839 & 0.121 & $0.179^{* *}$ & 2.9 & 8.6 & 0.099 \\
\hline \multicolumn{7}{|l|}{$\begin{array}{l}\text { Financial assets/ } \\
\text { Fixed assets }\end{array}$} \\
\hline Below median & 2,839 & 0.129 & $0.199^{* *}$ & 2.9 & 8.4 & 0.103 \\
\hline Above median & 2,839 & 0.155 & $0.311^{* * *}$ & 5.0 & 25.3 & 0.107 \\
\hline \multicolumn{7}{|l|}{ Total Debt/Assets } \\
\hline Below median & 2,839 & 0.141 & $0.205^{* * *}$ & 3.5 & 12.5 & 0.112 \\
\hline Above median & 2,839 & 0.143 & $0.318^{* * *}$ & 4.7 & 22.1 & 0.098 \\
\hline \multicolumn{7}{|l|}{ Supplier Debt/debt } \\
\hline Below median & 2,839 & 0.122 & $0.259^{* * *}$ & 3.9 & 14.8 & 0.090 \\
\hline Above median & 2,839 & 0.162 & $0.242^{* * *}$ & 4.1 & 16.8 & 0.123 \\
\hline
\end{tabular}

${ }^{*} p<0.1,{ }^{* *} p<0.05,{ }^{* * *} p<0.01$.

Table 7 shows the first-stage regressions presented in column (3) of Table 5 re-run on sub-samples, splitting firms by their financial characteristics. By sub-sample, column (1) shows the number of firms, column (2) the unconditional share of cases converted to RJ, column (3) the coefficient of the instrument share of other cases converted, interpreted as being the share of marginal firms, columns (4) and (5) the t-statistic and F-statistic respectively, and column (6) the fraction of firms that would be converted regardless of the Court. The "Other" category includes the Manufacturing and Transport industries. 
Table 8: Exclusion Restriction

\begin{tabular}{lcc}
\hline \hline Dependent variable: & \multicolumn{2}{c}{ Debt restructuring in RJ } \\
\cline { 2 - 3 } & All RJ & Voluntary RJ \\
& $(1)$ & $(2)$ \\
\hline Share of cases converted & 0.00871 & 0.00497 \\
& $(0.87)$ & $(0.41)$ \\
Ln(\# & $0.00925^{* * *}$ & $0.00389^{*}$ \\
Age $>$ 5 y years old) & $(4.95)$ & $(1.80)$ \\
& $0.120^{* * *}$ & $0.110^{* * *}$ \\
Zombies & $(30.27)$ & $(21.86)$ \\
& $-0.0235^{* * *}$ & $-0.0359^{* * *}$ \\
Fixed asset/asset & $(-5.70)$ & $(-6.98)$ \\
& 0.00482 & 0.00152 \\
Financial asset/fixed asset & $(0.82)$ & $(0.63)$ \\
& -0.0169 & $-0.0519^{* * *}$ \\
Total debt/asset & $(-1.43)$ & $(-4.78)$ \\
& $-0.0127^{* * *}$ & $-0.0123^{* * *}$ \\
Supplier debt/debt & $(-5.04)$ & $(-3.74)$ \\
& $-0.103^{* * *}$ & $-0.0932^{* * *}$ \\
Legal-status dummies & $(-9.68)$ & $(-7.56)$ \\
\hline Court fixed effects & Yes & Yes \\
Industry $\times$ Year-of-filing fixed effects & Yes & Yes \\
& & Yes \\
Observations & 66,849 & 39,565 \\
Adjusted R-squared & 0.087 & 0.119 \\
\hline \hline$t$ statistics in parentheses. & & \\
${ }^{*} p<0.1,{ }^{* *} p<0.05,{ }^{* * *} p<0.01$. & & \\
\end{tabular}

Table 8 presents a test for the exclusion restriction. We run the reduced form of our model (equation (7D) with debt restructuring in RJ as the dependent variable. We assume that if the propensity to convert has no impact on debt restructuring in RJ, it will have no impact in Sauvegarde either, which is very similar. Column (1) shows the regression results for the sample of all RJ, and column (2) those for the sub-sample of voluntary RJ filers. Voluntary RJ filers are the most similar to Sauvegarde filers, as they are likely to be more pro-active in the face of financial difficulties. Standard errors are clustered at the Court-year of judgment level. 
Table 9: Main Results

\begin{tabular}{|c|c|c|c|}
\hline Dependent variable: & $\overline{\text { Debt Res }}$ & reructuring & $\overline{\overline{E S} / \mathrm{NO})}$ \\
\hline Model: & $\begin{array}{l}\text { OLS } \\
(1)\end{array}$ & $\begin{array}{c}\text { IV-2SLS } \\
(2)\end{array}$ & $\begin{array}{c}\text { IV-2SLS } \\
\text { ACvsCC } \\
\quad(3)\end{array}$ \\
\hline Conversion to RJ & $\begin{array}{c}-0.562^{* * *} \\
(-29.74)\end{array}$ & $\begin{array}{c}-0.497^{* * *} \\
(-3.22)\end{array}$ & $\begin{array}{c}-0.518^{* * *} \\
(-4.16)\end{array}$ \\
\hline Ln(employees) & $\begin{array}{c}0.0333^{* * *} \\
(6.98)\end{array}$ & $\begin{array}{c}0.0320^{* * *} \\
\quad(5.71)\end{array}$ & $\begin{array}{c}0.0346^{* * *} \\
(6.59)\end{array}$ \\
\hline $\operatorname{Age}(>5$ years old $)$ & $\begin{array}{c}0.0874^{* * *} \\
(6.49)\end{array}$ & $\begin{array}{c}0.0885^{* * *} \\
\quad(6.61)\end{array}$ & $\begin{array}{c}0.0846^{* * *} \\
(6.27)\end{array}$ \\
\hline Zombies & $\begin{array}{c}-0.0437^{* * *} \\
(-3.56)\end{array}$ & $\begin{array}{c}-0.0449^{* * *} \\
(-3.62)\end{array}$ & $\begin{array}{c}-0.0489^{* * *} \\
(-3.94)\end{array}$ \\
\hline Fixed asset/asset & $\begin{array}{c}0.0588^{* * *} \\
(2.61)\end{array}$ & $\begin{array}{c}0.0597^{* * *} \\
(2.71)\end{array}$ & $\begin{array}{c}0.0536^{* *} \\
(2.42)\end{array}$ \\
\hline Financial asset/fixed asset & $\begin{array}{c}-0.0634^{* * *} \\
(-3.02)\end{array}$ & $\begin{array}{c}-0.0641^{* * *} \\
(-3.08)\end{array}$ & $\begin{array}{c}-0.0621^{* * *} \\
(-2.93)\end{array}$ \\
\hline Total debt/asset & $\begin{array}{c}-0.0342^{* *} \\
(-2.48)\end{array}$ & $\begin{array}{c}-0.0344^{* *} \\
(-2.53)\end{array}$ & $\begin{array}{c}-0.0347^{* * *} \\
(-2.58)\end{array}$ \\
\hline Supplier debt/debt & $\begin{array}{c}-0.0179 \\
(-0.57)\end{array}$ & $\begin{array}{c}-0.0189 \\
(-0.60)\end{array}$ & $\begin{array}{c}-0.0234 \\
(-0.73)\end{array}$ \\
\hline Legal-status dummies & Yes & Yes & Yes \\
\hline Court fixed effects ${ }^{\star}$ & Yes & Yes & Yes \\
\hline Industry $\times$ Year-of-judgment fixed effects & Yes & Yes & Yes \\
\hline Observations & 5,678 & 5,678 & 5,678 \\
\hline Adjusted R-squared & 0.240 & 0.200 & 0.218 \\
\hline
\end{tabular}

The dependent variable is a dummy for the firm having reached a debt-restructuring agreement with its creditors. Conversion is a dummy for the firm having been converted from Sauvegarde to RJ. The regression in column (1) is estimated by OLS. The regressions in columns (2) and (3) are estimated by IV-2SLS, with the first stages being respectively in Table 5 column (2), and Table 6 column (2). 
Table 10: Impact of Conversion on Debt Restructuring on different subsamples

\begin{tabular}{|c|c|c|c|}
\hline Sub-sample & $\begin{array}{c}\text { Number of } \\
\text { observations } \\
\text { (1) }\end{array}$ & $\begin{array}{l}\text { OLS } \\
(2)\end{array}$ & $\begin{array}{c}\text { IV-2SLS } \\
(3)\end{array}$ \\
\hline \multicolumn{4}{|c|}{ Sub-samples based on SIV-2 digit } \\
\hline BtoB & 3,067 & $\begin{array}{r}-0.608^{* * *} \\
(-27.67)\end{array}$ & $\begin{array}{c}-0.350^{*} \\
(-1.87)\end{array}$ \\
\hline BtoC & 2,611 & $\begin{array}{r}-0.492^{* * *} \\
(-15.02)\end{array}$ & $\begin{array}{c}\mathbf{- 0 . 6 6 1}^{* *} \\
(-2.38)\end{array}$ \\
\hline Foreign & 1,923 & $\begin{array}{c}-0.568^{* * *} \\
(-17.29)\end{array}$ & $\begin{array}{l}-0.233 \\
(-0.80)\end{array}$ \\
\hline Domestic & 3,755 & $\begin{array}{c}-0.561^{* * *} \\
(-24.98)\end{array}$ & $\begin{array}{c}-\mathbf{0 . 6 5 6} \mathbf{6}^{\text {**** }} \\
(-3.90)\end{array}$ \\
\hline \multicolumn{4}{|c|}{ Sub-samples based on firm data } \\
\hline Foreign & 2,801 & $\begin{array}{c}-0.579^{* * *} \\
(-23.83)\end{array}$ & $\begin{array}{c}-0.490^{*} \\
(-2.51)\end{array}$ \\
\hline Domestic & 2,877 & $\begin{array}{c}-0.541^{* * *} \\
(-19.37)\end{array}$ & $\begin{array}{c}-\mathbf{0 . 5 4 8} \\
(-2.62)\end{array}$ \\
\hline
\end{tabular}

We present in Table 10 the OLS and IV estimates of Conversion on debt-restructuring on different sub-samples. We first use the 2-digit SIV codes to separate B-to-B firms from B-to-C ones, and firms in sectors with high level of export from firms with high level of domestic sales. We then use the income statement of the firm to split the sample into two sub-samples according to the share of foreign sales to domestic sales. The regressions contain the full set of controls and fixed effects used in column (2) of Table 5 . Standard errors are clustered at the Court-year of judgment level. 
Table 11: Robustness Test

\begin{tabular}{lcc}
\hline \hline Specification: & \multicolumn{2}{c}{$\begin{array}{c}\text { IV-2SLS exluding } \\
\text { the 25\% smallest Courts }\end{array}$} \\
\cline { 2 - 3 } Dependent variable: & $\begin{array}{c}\text { 1st stage } \\
\text { Conversion } \\
(1)\end{array}$ & $\begin{array}{c}\text { 2nd stage } \\
\text { Debt Restructuring } \\
(2)\end{array}$ \\
\hline Share of other cases converted & $0.328^{* * *}$ & \\
& $(4.58)$ & \\
Conversion to RJ & & $-0.395^{* *}$ \\
& & $(-2.19)$ \\
All control variables & & Yes \\
\hline All fixed effects & Yes & Yes \\
& Yes & 4,750 \\
Observations & 4,750 & 0.194 \\
Adjusted R-squared & 0.025 & \\
F-statistic for instrument & 20.96 & \\
\hline \hline$t$ statistics in parentheses. & & \\
${ }^{*} p<0.1,{ }^{* *} p<0.05,{ }^{* * *} p<0.01$. & &
\end{tabular}

We present in Table 11 a variant of the main specification in equations (3) and (4). We remove from our sample the 928 Sauvegarde cases that were assigned to the $25 \%$ smallest Commercial Courts. The first-stage estimate in column (1) uses the instrument share of other cases converted as in Table 5 column (2). The second-stage estimates appear in column (2). The regressions contain the full set of controls and fixed effects used in column (2) of Table 5 . Standard errors are clustered at the Court-year of judgment level. 
Table 12: Impact of Conversion on Survival

\begin{tabular}{|c|c|c|c|}
\hline & $\begin{array}{c}\text { Number of } \\
\text { Observations } \\
(1)\end{array}$ & $\begin{array}{l}\text { OLS } \\
(2)\end{array}$ & $\begin{array}{c}\text { IV-2SLS } \\
(3)\end{array}$ \\
\hline \multicolumn{4}{|l|}{ Survival rate after restructuring } \\
\hline 2 years after restructuring & 3,833 & $\begin{array}{l}0.041 \\
(1.15)\end{array}$ & $\begin{array}{c}\mathbf{- 0 . 1 8 4} \\
(0.49)\end{array}$ \\
\hline 4 years after restructuring & 3,053 & $\begin{array}{c}-0.087^{*} \\
(-1.80)\end{array}$ & $\begin{array}{c}-\mathbf{0 . 1 3 6} \\
(-0.29)\end{array}$ \\
\hline \multicolumn{4}{|l|}{ Unconditional survival rate } \\
\hline 3 years after filing & 5,678 & $\begin{array}{c}-0.471^{* * *} \\
(-26.27)\end{array}$ & $\begin{array}{c}-\mathbf{0 . 4 7 8} * * * \\
(-3.00)\end{array}$ \\
\hline 5 years after filing & 4,452 & $\begin{array}{c}-0.396^{* * *} \\
(-20.85)\end{array}$ & $\begin{array}{c}-\mathbf{0 . 4 3 4} * * \\
(-2.49)\end{array}$ \\
\hline
\end{tabular}

$t$ statistics in parentheses.

${ }^{*} p<0.1,{ }^{* *} p<0.05,{ }^{* * *} p<0.01$

The dependent variables are survival at the two- and four-year horizons after debt-restructuring, and three- and five-year horizons after bankruptcy filing. We display the coefficient of Conversion . The regressions in column (2) are estimated by OLS; the regressions in column (3) are the second-stage results of the IV-2SLS that uses the Court's annual share of other cases converted as the instrument (see the first stage in Table 5, column (3)). All of the regressions contain the full set of controls and fixed effects used in column (2) of Table 5. Standard errors are clustered at the Court-year of judgment level. 


\section{Appendix}

Table A.1: The share of Sauvegarde filings does not depend on the Court's past and present conversion rates

\begin{tabular}{lcc}
\hline \hline Dependent variable: & $\begin{array}{c}\text { Share of Sauvegarde filings } \\
\text { in year } t\end{array}$ \\
& $(1)$ & $(2)$ \\
\hline Share of cases converted & 0.0103 \\
$\quad$ in year $t$ & $(1.55)$ & \\
& & -0.0117 \\
in year $t-1$ & & $(-1.60)$ \\
& & \\
Annual local-level control variables & & \\
Share of direct liquidations & $0.0846^{* * *}$ & $0.0921^{* * *}$ \\
& $(2.85)$ & $(2.74)$ \\
Unemployment rate & 0.0308 & -0.0830 \\
& $(0.13)$ & $(-0.32)$ \\
Ln(\#bankruptcy filings) & $-0.0268^{*}$ & -0.00968 \\
& $(-1.95)$ & $(-0.64)$ \\
\hline Court fixed effects & Yes & Yes \\
Year fixed effects & Yes & Yes \\
Observations $($ Court $\times$ Year $)$ & 1,042 & 895 \\
Adjusted R-squared & 0.086 & 0.077 \\
\hline \hline$t$ statistics in parentheses. & \multicolumn{2}{c}{} \\
${ }^{*} p<0.1,{ }^{* *} p<0.05,{ }^{* * *} p<0.01$. &
\end{tabular}

The assignment to Courts is not random, but depends on the firm's location. We test in Table A.1 whether the share of Sauvegarde filing depends on the Court's track-record of conversion rates. The dependent variable Share of Sauvegarde filings is the ratio of Sauvegarde filings to all Sauvegarde and RJ filings at time $t$. The regressions are estimated at the Court level. Column (1) includes the years $t=2010$ to 2018, and column (2) $t=2011$ to 2018. 
Table A.2: The probability of entering Sauvegarde does not depend on the Court's past and present conversion rates

\begin{tabular}{lcc}
\hline \hline Dependent variable: & \multicolumn{2}{c}{ Filing for Sauvegarde in year $t$} \\
& $(1)$ & $(2)$ \\
\hline Share of cases converted & 0.00215 & \\
in year $t$ & $(0.26)$ & \\
& & -0.00882 \\
in year $t-1$ & $(-0.84)$ \\
& $0.00970^{* * *}$ & $0.00939^{* * *}$ \\
Ln(\#-employees) & $(5.14)$ & $(4.88)$ \\
& $0.0108^{* * *}$ & $0.00973^{* * *}$ \\
Age( $>5$ years old) & $(3.08)$ & $(2.63)$ \\
& $-0.0153^{* * *}$ & $-0.0162^{* * *}$ \\
Zombies & $(-3.89)$ & $(-3.91)$ \\
& $-0.0198^{* * *}$ & $-0.0176^{* *}$ \\
Fixed asset/asset & $(-2.62)$ & $(-2.23)$ \\
& $0.0697^{* * *}$ & $0.0703^{* * *}$ \\
Financial asset/fixed asset & $(6.50)$ & $(6.27)$ \\
& $-0.0212^{* * *}$ & $-0.0221^{* * *}$ \\
Total debt/asset & $(-7.81)$ & $(-7.56)$ \\
& $-0.0322^{* * *}$ & $-0.0250^{* *}$ \\
Supplier debt/debt & $(-3.16)$ & $(-2.31)$ \\
& Yes & Yes \\
Legal-status dummies & Yes & Yes \\
\hline Court fixed effects & Yes & Yes \\
Industry $\times$ Year-of-judgment fixed effects & 18,004 & 16,485 \\
Observations $($ Firms $)$ & 0.765 & 0.770 \\
Adjusted R-squared & & \\
\hline \hline$t$ statistics in parentheses. & & \\
${ }^{*} p<0.1,{ }^{* *} p<0.05,{ }^{* * *} p<0.01$. & &
\end{tabular}

The assignment to Courts is not random, but depends on the firm's location. We test in Table A.2 whether the probability that a firm enter Sauvegarde depends on its Court's trackrecord of conversion rates. The dependent variable Filing for Sauvegarde is 1 if the firm files for Sauvegarde at $t$ and 0 if it files for RJ. The regressions are estimated at the firm level. Standard errors are clustered at the Court-year of judgment level. Column (1) includes the years $t=2010$ to 2018 , and column (2) $t=2011$ to 2018 . 